\title{
Entre Largo e Praça, Matriz e Catedral: a Sé dos cartões postais paulistanos ${ }^{1}$
}

\author{
Fraya Frehse \\ Mestranda em Antropologia Social/USP ${ }^{2}$
}

Resumo: Este artigo é resultado das primeiras reflexões que venho realizando sobre o uso do cartão postal como fonte de análise antropológica, no âmbito de uma pesquisa de mestrado sobre as rupturas e continuidades culturais experienciadas pelos habitantes de São Paulo frente às transformações socioculturais por que passou a cidade a partir dos anos 1870. Num cenário de Ouro-Preto-que-vira-Paris, quais as imagens de cidade que o cartão postal, surgido em São Paulo em fins do XIX, veicula? Concebendo o postal como representação simbólica da constituição de toda uma dinâmica cultural que se reflete profundamente na identidade que o paulistano passou a construir em relação a sua cidade, o objetivo aqui é tentar entender quais as dimensões de cidade que treze imagens produzidas entre fins do XIX e os anos 60 deste século sobre um local de importância histórica e social como o Largo/Praça da Sé expressam, pois que se concebe que elas sejam o modo pelo qual a São Paulo que muda de forma vertiginosa a partir da década de 1870 se vê e quer ser vista pelo "outro" distante espacial e/ou temporalmente.

Unitermos: São Paulo, virada do século XX, símbolos de modernidade, dinâmica cultural, cartão postal.

\footnotetext{
“A catedral de São Paulo

Por Deus! que nunca se acaba

- Como minha alma.

É uma catedral horrível

Feita de pedras bonitas

- Como minha alma.

A catedral de São Paulo

Nasceu da necessidade

- Como minha alma.

Sacro e profano edifício,

Tem pedras novas e antigas

- Como minha alma.

Um dia há de se acabar,

Mas depois se destruirá

- Como o meu corpo.

[...]"
}

Mário de Andrade ("Lira Paulistana", 1946) 


\section{INTRODUÇÃO}

São Paulo. Quem pronuncia o nome da cidade hoje é levado quase que intuitivamente a associá-lo a termos como "metrópole", "multidão", "trânsito", "caos". Termos que apontam para algumas das múltiplas facetas que a cidade foi construindo para si ao longo do tempo, mas que parecem perenes. Afinal, uma vez que a São Paulo que se apresenta ao olhar do observador está em constante mutação pela "força da grana que ergue e destrói coisas belas", como já sintetizou brilhantemente o poeta baiano, a primeira impressão que se tem é que São Paulo nunca "foi", de fato; sempre "esteve".

A diferença entre os verbos "ser" e "estar", quase que exclusiva da língua portuguesa, encontra nesta cidade seu exemplo mais acabado: São Paulo nunca $e ́$, porque ser implica uma constância que se materialize no espaço, constituindo um passado e um presente; ao contrário, ela continuamente está... - rumo ao "desenvolvimento", ao "progresso", ao "futuro"... Construir-se no intenso vagar sem nunca parar entre os tempos passado, presente e futuro - eis a dinâmica que dá sentido à impressão do antropólogo Claude Lévi-Strauss, quando chega à cidade em 1935: "nas metrópoles do Novo Mundo, seja Nova Iorque, Chicago ou São Paulo, que se lhe costuma comparar, não é a falta de vestígios que me choca; essa ausência é um elemento de sua significação". De forma que o que se torna fundamental para o observador é se "adaptar a um sistema sem dimensão temporal, para interpretar uma forma diferente de significação" (Lévi-Strauss, 1957:96).

Partindo dessa perspectiva é que venho estudando o fin de siècle

pauıstano, a 1ım de entender como se engendrou o processo de significações que construiu e reconstrói, a cada momento, esse "sistema sem dimensão temporal" que é a São Paulo visitada por Lévi-Strauss nos anos 30, que é a São Paulo vivenciada por nós nos anos 90 .

Voltar no tempo até 1870 , que é a década em que se inicia, por parte das oligarquias cafeeiras paulistas, inseridas nos mecanismos do capital agro-exportador, o "projeto" de inscrever, na villa imperial de São Paulo, a força econômica conquistada pela Província com a produção do café. Firente às transformações por que a cidade passou, pretendo debruçar-me sobre a dinâmica cultural que mistura o "colonial" e o "moderno", a São Paulo da taipa e a do tijolo, do carro de bois e do bonde elétrico, do candeeiro e da iluminação a gás, do chafariz e da água encanada...

O que chamo de dinâmica cultural'? O processo de construção de múltiplos significados engendrados pela inserção de novos valores e costumes no contexto social predominantemente rural que é a villa na década de 1870. A fim de apreender este jogo de espelhos de infinitos sentidos, a opção teórico-metodológica é destrinchar as noções de tempo e espaço que perpassam discursos e imagens da cidade daquela época. Como nos diz Émile Durkheim, as categorias de tempo e 
espaço, noções essenciais que dominam a vida intelectual, são sociais e "se caracterizam por possuírem um valor objetivo" (1937/1922: 21), assumindo o papel de símbolos quando desviadas de seu significado original.

Assim, "procurá-las" permite, por um lado, analisar, nos objetos que invadem o cenário paulistano a partir de fins do XIX, especificamente os significados que estes carregam, uma vez que são representações simbólicas do "moderno" propagado pelas elites cafeeiras que deve se corporificar no espaço físico e nos equipamentos urbanos da cidade. Por outro lado, ter como norte metodológico as categorias de tempo e espaço possibilita levar em conta outros objetos, outros símbolos, ligados ao passado propriamente colonial da cidade e que se exprimem na "pacatez", no "provincianismo" que os cronistas enxergam, durante todo o século XIX, na vida na Paulicéia.

Neste artigo, focalizo alguns aspectos de construção dessa dinâmica cultural analisando um dos vários objetos que, sendo imagens, representam simbolicamente as transformações pelas quais a cidade passou a partir de fins do século XIX: o cartão postal que, fotografia, é um dos parâmetros para "o conhecimento que temos do que foi o passado e do alcance do presente" (Sontag, 1986:15).

Em sua essência, esse objeto é uma fotografia reproduzida en masse para o comércio, que permite, além da "acumulação de símbolos do eu e sinais de possessão individual" (Corbin, 1995: 421), que sejam extravasados sentimentos que se têm com relação à cidade em que se vive, pois os cartões são, antes de tudo, objetos de circulação: devem ser enviados e, nesse movimento, expressar sentimentos pessoais ligados a fatos cotidianos e ao cenário que constitui o cartão.

O cartão surge na Europa da década de 1860, a partir de iniciativas oficiais, voltadas exclusivamente para o desenvolvimento de um meio de correspondência postal rápido e barato. Isso implica que os postais tenham uma estrutura muito simples. De fato, no início eles consistem num pedaço de cartolina retangular sem qualquer imagem: um lado, a "frente" do cartão, se destina ao endereço do destinatário; o outro exclusivamente à mensagem escrita.

Devido aos altos custos envolvidos na reprodução de imagens, os correios nacionais só as inserem nos postais em ocasiões $\mathrm{e}$ festividades oficiais. Esse aspecto e as crescentes facilidades tecnológicas envolvidas na reprodüção de imagens $^{3}$ acabam, na última década do século, por inspirar particulares a produzirem os seus próprios cartões com imagens - inicialmente a partir de autorização dos correios, depois não mais -, o que contribui para a difusão destes pelos quatro cantos do mundo 4 .

Resultado? O postal assume uma nova feição: a "frente" do postal permanece livre para o registro dos dados do destinatário, enquanto o "verso" se destina ao texto e à imagem, que aparece como vinheta. Com o tempo, mais uma mudança, que dará ao postal o aspecto que tem atualmente: a "frente" muda de lado, por assim dizer, contendo agora a imagem, enquanto o "verso" é comparti- 
lhado pelo texto e o endereço do destinatário.

Levar em consideração as mudanças de layout do postal, permite entendêlo como fragmento de um processo cultural maior por que passa a sociedade ocidental a partir de fins do século XIX. Processo este que faz com que o texto escrito se curve frente à imagem que, assumindo o primeiro plano, aborda, nos postais da virada do século, os mais diversos temas:

"a caricatura política; a crítica dos costumes; a crítica à guerra; os retratos de personagens de destaque do meio artístico da época; as montagens e fotomontagens de toda ordem; os bem cuidados temas, particularmente alusivos à figura feminina, criados pelos mestres do art-nouveau; os temas ligados ao erotismo, compreendendo inúmeros aspectos que iam desde.

possa imaginar; as fotos de acidentes e catástrofes, além das vistas de ruas, cidades e monumentos: os tradicionais postais de interesse turístico" (Kossoy, 1978).

No Brasil, pode-se afirmar que os cartões vêm basicamente com os imigrantes que, chegando da Europa, trazem consigo o hábito de se comunicar via postais. Sintetiza Kossoy que aqui "o cartão postal (...) foi utilizado desde o início do século contendo particularmente reproduções de vistas de cidades e de temas comemorativos de exposições importantes como a Exposição Nacional de 1908, a Exposição Centenário, em 1922, além de outros eventos”. Seus autores? Fotógrafos famosos no cenário paulistano e carioca da época, como Guilherme Gaensly, Marc Ferrez e J. Marques Pereira ${ }^{5}$. Veiculam-se, entre outros, publicidades e paisagens urbanas das principais cidades brasileiras da época: Recife, Rio de Janeiro, Salvador, Campinas, São Paulo...

Selecionei, como objetos de estudo, os postais do colecionador particular João Emílio Gerodetti relativos ao antigo Largo da Sé (atual Praça da Sé) entre fins do século passado e 1969, que é quando a nova catedral da Sé - que existe ainda hoje - é inaugurada, após um período de 57 anos de construção.

Por que escolhi a Sé? O arquiteto Santos Junior vê o local como "um elemento peculiar da estrutura urbana paulistana por apresentar uma grande significação histórica, funcional e simbólica para a cidade", além de ser, "dentre os espaços públicos mais antigos da cidade (...) o que coriheceu a transformação mais radical, tendo sua área física e sua importância funcional ampliadas significativamente no último século" (1991: 9).

Tudo isso contribui para que no Largo/Praça vivam e convivam temporalidades e espacialidades várias, do passado colonial da villa e do presente "moderno" daquilo que Bruno (1954) chama "metrópole do café". Trata-se, então, de desvendar as várias camadas de significação ocultas por trás dos cartões desse local específico da cidade e relativas ao contexto social paulistano das primeiras décadas do presente século. Pois que elas, expressando o modo pelo qual a São Paulo que muda de forma vertiginosa a partir da década de 1870 se vê e quer ser vista por aquele que não a conhece, acabam por compor, em conjunto, uma imagem contraditória de cidade. Cidade do novo tempo, mas fundamentalmente 
velha. Cidade de espaços urbanos, onde o rural insiste em aparecer e ser...

\section{Percursos da Sé na história}

Para uma análise de imagens do passado é fundamental, segundo Miriam Moreira Leite, "o conhecimento prévio e direto da realidade que a imagem representa, simboliza ou indica, para não se ficar desorientado com seus elementos constitutivos" (1993: 158). Isso vale também para o estudo do Largo/Praça da Sé, cuja história revela a importância do local para a cidade, dos cartões desse local para o observador.

Por mais interessante que seja uma retrospectiva de toda a história do Largo desde fins do século XVI - quando foi pensada para o local a primeira e modesta igreja matriz em São Paulo -, passo aqui a acompanhar os percursos históricos do Largo a partir de fins do século XIX, quando surgem os primeiros postais que o tematizam.

Até a década de 1870, a villa imperial de São Paulo é um universo social basicamente rural. Para além dos ventos cosmopolitas trazidos à cidade pela Academia de Direito, inaugurada em 1828, predominam na cidade um "relativo isolamento e provincianismo; a modesta economia de subsistência de seus arredores, refletindo-se na configuração urbana e na vida de seus habitantes; a importância das relações pessoais, a unidade devida aos ritos e festejos de uma mesma fé" (Morse, 1970: 23).

A importância do então Largo da Sé na villa se deve basicamente ao fato de concentrar, além dos sobrados dos membros mais abastados da incipiente população paulistana, a catedral da Sé6. Erigido em inícios do século XVII como no local onde havia antes a igreja-matriz de São Paulo ${ }^{7}$, o templo mantém, ainda em fins do XIX, a aparência de seus primórdios: é "pouco mais que uma simples capela, menor e muito menos importante que a igreja dos jesuítas, situada logo abaixo, no Pátio do Colégio" (Miyazaki et alii, 1979: 5). Com sua "fachada sombria e triste" e um "portal branco encimado pela coroa real portuguesa" (Bruno, 1954), a catedral permanece até os anos 1870 o ponto de encontro da população aos domingos; o ponto de partida e chegada das procissões nos dias santos.

$\mathrm{O}$ contexto econômico de expansão do capital ligado à segunda Revolução Industrial (Smreczsányi, 1986) implica a consolidação, na província de São Paulo, daquilo que alguns autores chamam de "complexo cafeeiro". Com a prosperidade econômica das fazendas de café do Oeste paulista, na década de 1870, a província de São Paulo se torna o mais importante pólo econômico do país.

Chegam à capital da província muitos imigrantes, escravos fugidos das fazendas; vêm para a cidade os fazendeiros de café. Para além das suas possibilidades sociais, políticas e econômicas, a cidade oferece-se também como palco para a produção e difusão de símbolos que representem o poderio econômico dos grupos que a dominam. Esses "símbolos de civilização, ícones de nossa cultura" 
(Schwarcz, 1994) fortemente referidos a todo um ideário permeado por termos que giram em torno de "modernidade" no sentido cunhado por Perry Anderson (1986), tornam-se os ideais que as elites cafeeiras paulistas jogam, projetam sobre o solo sociocultural de países como o Brasil, para cidades como São Paulo, a partir do último quartel do XIX.

É com João Teodoro Xavier de Matos na presidência da província de São Paulo, entre 1872 e 1875, que esse projeto se inicia. Vale aqui enfatizar que, dentre as várias medidas do governador, está a substituição, em 1872, dos lampiões a querosene do Largo da Sé pela iluminação a gás; o calçamento do Largo com paralelepípedos, em 1873; o início do serviço de bondes puxados a burro, cujo ponto principal se situa em frente à Catedral. Se já desde 1865 o local era estacionamento de tílburis, agora institucionaliza-se - e para sempre - o seu papel de terminal ou entroncamento viário, na cidade.

Em 1884, ocorre a primeira reforma maior do Largo, já que "suas dimensões já não correspondiam ao desenvolvimento da cidade e às exigências do comércio estabelecido nele e em suas periferias, pois São Paulo começava a enriquecer, sob a influência do surto cafeeiro, convertendo-se em importante entreposto comercial" (Miyasaki et alii, 1979:11). A reforma incide primordialmente sobre a catcdral: são reformados o seu frontispício e a torre (Martins, 1911), de forma que, nos últimos anos do século passado, o Largo já é "um local onde começa a se manifestar com intensidade a atividade comercial, um ponto de reunião e de distribuição de trânsito e de pedestre para a área próxima" (Santos Jr., 1991: 18)9 .

A República cria espaço para a primeira administração municipal da cidade, em 1891. O fazendeiro e prefeito Antônio Prado, cujo mandato dura doze anos (1898-1910), consegue implementar os projetos de modernidade idealizados para São Paulo, dentre os quais quero destacar aqui a demolição, em 1912, da velha catedral da Sé, situada muito abaixo da atual catedral. O objetivo é construir uma outra catedral, "de maiores proporções, mais ao gosto da época e condizente com o novo 'status' da cidade" (Haddad apud Miyazaki et alii, 1979).

Demolida a velha igreja da Sé e os três quarteirões que separavam o largo de São Gonçalo, eis que têm lugar as discussões sobre o projeto da nova catedral. Sob a coordenação do arquiteto alemão e professor da Escola Politécnica Max Hehl, inicia-se em 1913 a construção do novo templo, em estilo gótico, que deve ter 112 metros de altura 47 de largura, e uma capacidade para abrigar aproximadamente oito mil pessoas (Bruno, 1954):

"Afastar o passado colonial", eis o lema. Destruir três quadras de casas de taipa para construir a Catedral é o pretexto para transformar o antigo largo em ampla praça cinco vezes maior ${ }^{10}$. Explica o historiador Nicolau Sevcenko sobre os extáticos anos 20 paulistanos: "como (...) a maior área livre do núcleo central de São Paulo - planejada para ser a maior da América Latina e quiçá de todo o continente americano -, a determinação é unânime: transformar o Largo da Sé na praça 
cívica da cidade, fazendo convergir assim os símbolos da fé, da pujança e da alma coletiva" (1992: 103). Os velhos edifícios coloniais cedem lugar aos cada vez mais numerosos automóveis; ensaia-se a implantação de ícones de modernidade propriamente urbanos como pontos de ônibus, relógios, estátuas, cartazes de propaganda, construídos para serem destruídos mais tarde, derrubados no intuito de depois serem refeitos.

Em 1934, implanta-se na Praça o marco zero da cidade, o que "representava o marco das distâncias oficialmente medidas, reatando a tradição secular que contava as léguas a partir da porta da Igreja da Sé" (Barros Ferreira apud Santos Jr., 1991: 86). Assim, é inscrita espacialmente no novo velho local a sua dimensão simbólica de coração da cidade, em detrimento mesmo do Pátio do Colégio, espaço em que, historicamente, "tudo começou". E a Praça continua caracterizada por ser ponto de entroncamento dos transportes públicos, o que causa grandes congestionamentos, além de abrigar "serviços e equipamentos culturais voltados para as camadas que a frequientam".

É no final da década de 40 que a Praça começa a perder prestígio no cenário urbano. Depois da conclusão do novo Viaduto do Chá, em concreto armado, em 1935, começa a paulatina transferência do comércio de luxo e de artigos finos, dos cinemas, teatros e casas noturnas para o "centro novo" a oeste do Vale do Anhangabaú. O que resta à Praça é ser, além de ponto de entroncamento viário, o centro do comércio de artigos baratos; os elegantes escritórios mudam para outros locais da cidade ${ }^{11}$.

Em 1952, inicia-se uma reforma no local, a fim de prepará-lo para as comemorações do Quarto Centenário. Conta-nos Santos Jr. que

"o espaço fronteiro à Catedral deixava de ser estacionamento, transformando-se numa esplanada de piso em mosaico preto e branco onde foram plantadas palmeiras imperiais. O espaço intermediário, onde ficava o antigo abrigo de bondes, passava a ser ocupado com quatro abrigos de ônibus paralelos às laterais da Praça" (1991:79).

E eis que chega o 25 de janeiro de 1954, data do quarto centenário da cidade, momento em que a Catedral é inaugurada. Não está concluída de todo, é fato. Afinal, faltam-lhe ainda as duas grandes torres frontais inscritas no projeto original que são construídas mais tarde. Mas já existe o templo imponente, na frente do qual se concentra o mais importante terminal de transporte público (bondes e ônibus) da cidade. Há também a nova estátua de José de Anchieta. Foram plantadas árvores e instalados bancos de praça em alvenaria.

Nem as festividades em torno do Quarto Centenário atenuam o deterioramento da Praça. A transferência dos terminais de ônibus, de lojas e restaurantes para outros locais da cidade esvazia crescentemente o local, de forma que, quando chega 1969 e a Catedral é totalmente concluída, pelo menos para os grupos que a pensaram e planejaram, não há mais muito o que comemorar. O templo e a praça, pensados num só tempo, ao serem concluídos, chocam-se por estarem 
imbuídos de temporalidades distintas: a catedral atesta uma conjunção de projeto e glamour de já meio século de idade, idoso, passado, no interior de um espaço tornado dejeto no presente em meio a novas sociabilidades surgidas, porque os tempos são outros, o paulistano é outro, a cidade mudou.

Especificamente por ser tão carregada de significados culturais é que a Praça se perpetua nos cartões postais da cidade, veiculados a partir da última década do XIX. O Largo é um só; os ângulos enquadrados, as cenas focalizadas variam de acordo com os valores en vogue nos mais diferentes momentos históricos. Eis o que vale descobrir: quais os significados que se escondem por sob as cenas do Largo/Praça retratados nos cartões nos diferentes momentos históricos e que fornecem ao observador o jogo de olhares pelos quais o paulistano das primeiras décadas deste século estabelece sua identidade com a Paulicéia.

\section{Percursos da Sé nos postais}

Analisar os postais fotográficos paulistanos do período implica levar em consideração alguns aspectos metodológicos relativos ao seu duplo viés de objeto de correspondência postal e visual - cujo sentido se realiza na circulação comercial cm um determinado contexto social - e de imagem - portanto, "registro visual a partir de aspectos selecionados do real" que significa a partir do momento em que é produzido (Kossoy, 1988).

Sendo um objeto, o cartão postal carrega em si a ambigüidade de ser fotografia - portanto, "o Particular absoluto, a Contingência soberana" - e objeto de correspondência entre as pessoas - ou seja, mercadoria que "reproduz infinitamente aquilo que não teve lugar mais que uma vez: ela repete mecanicamente" (Kossoy, 1988; grifo meu). No bojo disso, é interessante notar a estrutura do cartão postal em seus primórdios: sua frente é composta pela imagem, que ocupa o espaço completo ou parcial do cartão, a fim de que nesse mesmo lado seja escrita a mensagem. O verso do cartão é destinado exclusivamente ao registro dos dados do destinatário e ao selo. Vê-se, portanto, um objeto de correspondência no qual tão importante quanto a mensagem escrita é a imagem, de forma que o fundamental é ambas dividirem o espaço físico do cartão: não basta mostrar o lá; é necessário registrar e comprovar a minha presença nesse lá... ${ }^{12}$

Sendo imagens, os cartões contêm as características dessas. Explica Barthes que "a imagem é polissêmica e pressupõe, subjacente a seus significantes, uma 'cadeia flutuante' de significados, podendo o leitor escolher alguns e ignorar outros", já que "a polissemia leva a uma interrogação sobre o sentido" (1990: 32).

Eis um ponto de partida analítico interessante, pois permite enxergar as imagens dos cartões postais antigos de São Paulo como caleidoscópios repletos de códigos que veiculam os mais diversos significados, relativos, por um lado, ao contexto sociocultural em que surgiram. Afinal, não se pode esquecer que o que 
faz os diversos fotógrafos "elegerem" tais ou quais objetos e cenas como focos privilegiados de suas câmeras é, antes de tudo, um complexo de valores e de situações que subsidiam os significados que aqueles objetos ou cenas possuem para o próprio olhar que fotografa naquele determinado momento histórico. No caso específico da São Paulo da virada do século, deve-se levar em conta que as imagens veiculadas pelos postais se referem, em sua grande maioria, a uma concepção de cidade germinada prioritariamente no interior das altas rodas paulistanas. Afinal, as fotografias são produzidas por fotógrafos da cidade que, membros ou não dos grupos mais abastados da sociedade paulistana, entusiasmados ou não com o "moderno", dependem economicamente da demanda de serviços por parte de quem consome majoritariamente essas imagens, naquele momento. Os símbolos de modernidade trazidos e admirados pelas elites tomam, portanto, conta das fotografias, dos postais: o férreo Viaduto do Chá, o reluzente Palácio do Governo, o imponente Teatro Municipal, a gótica Catedral da Sé...

Por outro lado, os significados transmitidos nos cartões postais do passado paulistano se relacionam profundamente com a conjuntura sociocultural do próprio observador. Desencadeando um complexo de significados culturais pois que simbólicos, a fotografia fala ao contexto social do presente como esse mesmo era no passado e não o é mais, uma vez que "as calegorias através das quais o mundo atual é orquestrado assimilam algum novo conteúdo empírico" diferente do que havia, diferente do que é trazido pelo passado (Sahlins, 1990: 181).

Precisamente essa conjugação de dimensões é que tira da fotografia o seu caráter de pura reprodução do real e faz com que a historiadora Miriam Moreira Leite privilegie a definição de que

"a fotografia é o ponto de encontro das contradições entre os interesses do fotógrafo, do fotografado, do leitor da fotografia e dos que estão utilizando a fotografia. Cada um deles verá de maneira difcrente a mesma fotografia, pois o ato de olhar demonstrou ser uma interação entre características do objeto e a natureza de quem o observa" (1993:145).

A fotografia como caleidoscópio de infinitos olhares, interesses... Cabe, portanto, ao observador dos cartões definir um tipo de olhar específico que lançará sobre esse caleidoscópio que cada fotografia do cartão na verdade é, dependendo das características que lhe atribui. É-lhe mais importante tomar as imagens retratadas nos cartões como pontes que permitam a ele avaliar, no presente, a sua própria relação com o passado retratado? Ou privilegia concebê-las como testemunhos documentais que lhe possibilitam o acesso a características desse passado que "falam", de alguma forma, do presente do observador? Falo aí de dois vieses de análise: do estudo da relação memória-história ou exclusivamente da história a partir dos cartões.

O que vale aqui é assumir a segunda opção como perspectiva analítica para a análise dos cartões, sem, contudo, reduzir a análise à reconstituição do contexto social de uma época a partir das imagens, como o sugere Kossoy (1980). 
Afinal, a história do passado estudada sempre revela ao observador do presente características deste mesmo presente. Como diz John Berger, "nunca olhamos apenas uma coisa [neste caso, o contexto histórico da imagem do cartão postal]; estamos sempre olhando para as relações entre as coisas e nós mesmos [o que aquele contexto revela sobre o nosso próprio momento histórico]"' (Berger apud Leite, 1993: 30).

Definido como olhar os cartões, é importante discutir o que olhar. Decifrar a polissemia de qualquer imagem fotográfica histórica implica compreender, por um lado, o onde retratado. Como nos diz a historiadora Miriam Moreira Leite, "a noção de espaço é a que domina as imagens fotográficas explícitas". Sendo produto do modo como uma determinada sociedade percebe e vivencia a sua relação com o espaço que a envolve, a dimensão espacial é capaz de "revelar comportamentos, representações e ideologias" através de "arranjos espaciais", permitindo, assim, a compreensão da "mensagem manifesta" na imagem. Segundo Leite, esses "arranjos" são "características da imagem: tamanho, formato, suporte, enquadramento, nitidez, planos, horizontalidade e verticalidade", além de "indumentária, objetos, desenvolvimento urbano, expressões de tecnologia" (1993:19).

Sob esse ângulo, os espaços de São Paulo retratados nos cartões de fins do século XIX e meados do XX ganham, para o observador, novos matizes. Sendo pontos da cidade que as elites querem promover através de símbolos específicos - o bonde, o relógio, o edifício "moderno" -, essas referências espaciais expressam a imagem de cidade que essas mesmas elites querem que seja veiculada à distância temporal e espacial, além de testemunharem também inevitavelmente outros modos pelos quais o tempo e o espaço foram percebidos pelos habitantes em cada momento histórico eternizado pela câmera fotográfica, e que se relacionam de alguma forma com o hoje da metrópole.

Outro parâmetro fundamental e problemático para a compreensão dos postais é a dimensão temporal, o quando. Problemático porque os cartões se caracterizam precisamente pela ausência de quaisquer datas, quer de edição do postal, quer do registro fotográfico. Referindo-se às imagens fotográficas históricas, Miriam Moreira Leite aponta que "o eixo temporal precisa ser construído pelo pesquisador, através da formação de seqüências cronológicas ou culturais" (1993: 19), eventuais detalhes e objetos presentes na própria imagem.

Pode-se destacar, primeiramente, as propagandas. Afinal, o momento histórico da "virada" é marcado pelo desenvolvimento dessa indústria em todo o mundo. Assim, a presença do cartaz de um produto específico que-só-surgiu-noano-tal poderia revelar com relativa precisão o período em que a fotografia foi feita. O problema é, entretanto, que a presença de um cartaz publicitário num cenário como o Largo da Sé não garante que o produto promovido tenha sido produzido naquele mesmo momento, uma vez que não se sabe se o cartaz foi ou não afixado no local no momento do surgimento do produto no mercado. Em tese, poderia ser que a propaganda de um produto ficasse anos a fio num local específico da cidade 
por uma razão qualquer: seja porque o dono da casa em cujo muro foi colocado o cartaz é o dono da firma que produz o objeto, ou porque o cartaz simplesmente permaneceu como resíduo do que já se perdeu, em meio à fumaça dos carros, ao chiar dos freios dos bondes, ao bater de pernas dos transeuntes pelas ruas...

Por isso mesmo, a utilidade da propaganda como parâmetro de datação das fotografias de paisagens urbanas é restrita. O máximo que se consegue a partir do elemento "propaganda" tomado isoladamente é, confrontando as referências observadas na imagem com dados presentes em bibliografia específica sobre a história da fotografia, determinar o momento a partir do qual uma imagem pode ter sido produzida.

Dada a complexidade envolvida nas datações por meio das propagandas, relembremos, com o pesquisador Robert Pols (1993), a aparência dos edifícios retratados, se forem "identificáveis e demonstrativamente muito novos ou, melhor ainda, estejam sendo construídos” (Pols, 1993:40). Além desses elementos, são úteis também para datação as invenções tecnológicas. Dentre essas quero destacar os automóveis que, surgidos para poucos no fin de siècle, invadem o mundo e as fotografias urbanas de todos, a partir dos primeiros anos do século XX. A existência de alguns modelos, mas ainda não de outros, delimitam um intervalo de tempo.

Deve-se enfatizar que a datação da imagem fotográfica fixada no cartão não implica que se tenha descoberto o momento de produção e circulação do objeto postal. Afinal, é uma característica estrutural do cartão, como meio de correspondência que é, produzido para o comércio seqüencialmente ou não em intervalos variáveis de tempo, a incompatibilidade entre o período de produção da imagem cartão e o de circulação do objeto cartão. Por isso não se tem qualquer tipo de garantia de que um postal com uma imagem que aparentemente data dos anos 10 deste século tenha realmente circulado naquele momento. Monsenhor Jamil resolve essa questão explicando que, mesmo havendo possivelmente essa diferença de datas, pode-se pressupor que ela se mantenha pequena nos cartões de circulação comercial, já que os próprios editores destes se interessam por manter sempre atual o seu estoque de imagens da cidade para melhores vendas. Assim, vão refazendo as imagens fotográficas dos diversos locais, quando estes alteram a sua aparencia rapidamente, e circulando-as no mesmo ritmo.

Destacados esses detalhes metodológicos, vamos aos cartões. O conjunto de cartões analisados aqui compreende algumas das mais características e freqüentes vistas do Largo/Praça da Sé desde a virada do século XX até $\mathrm{o}$ final dos anos 60 deste século. A fim de garantir a homogeneidade da amostra, esta contém exclusivamente cartões feitos a partir de fotografias em preto e branco: o cartão 2 é o único que apresenta uma reprodução impressa de imagem fotográfica; todos os outros foram feitos em laboratório fotográfico em tiragens limitadas e sucessivas, pelos diversos editores, anônimos ou não.

Já que a quase-totalidade dos postais da amostra não apresenta em seus versos mensagens escritas, optou-se por considerar como objetos específicos de 
análise somente as frentes dos cartões, que são imagens, permeadas ou não por textos escritos pelos consumidores dos cartões.

\section{Cartão 1}

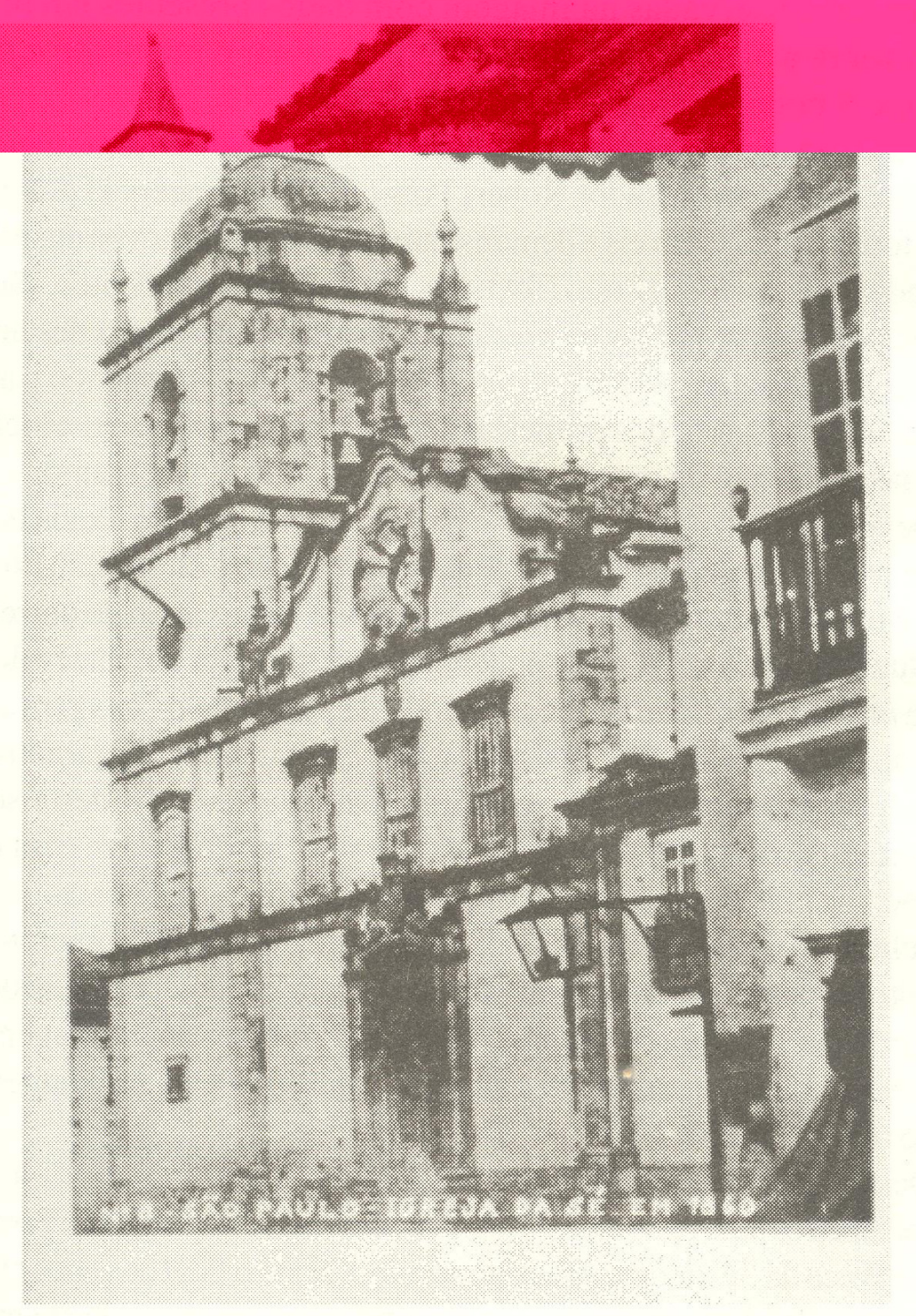

A fim de mostrar o que eram o Largo e a catedral da Sé antes de seu desaparecimento, em 1912, introduzo a análise por meio deste cartão peculiar. Sui 
generis porque, como objeto cartão, faz parte de uma edição comemorativa da década de 1950 que não circulou comercialmente, produzido na ocasião das festividades do Quarto Centenário da cidade de São Paulo para lembrar o passado colonial paulistano. Sui generis também pois que a imagem cartão retratada é de um momento bem anterior a 1950. Trata-se de um registro do famoso fotógrafo carioca Militão Augusto de Azevedo que, preocupado em perpetuar a aparência da São Paulo das décadas de 1860 e 1880, focalizou, em 1862, ângulos específicos da antiga São Paulo, voltando a fotografá-los depois de 25 anos para compor o seu Álbum comparativo da cidade de São Paulo (1862-1887) e mostrar como a cidade se desenvolvera no ínterim. Assim, permitiu que, depois de mais de um século, tenhamos uma noção do que era esta cidade antes das reformas de João Teodoro, e depois das transformações por que passou no período de 25 anos.

A imagem que o cartão contém foi feita a partir da esquina da rua Direita em direção à antiga Igreja da Sé13. Vê-se, com a ajuda de Miyazaki et alii, que

\begin{abstract}
"naquela época, o Largo da Sé era um lugar muito prestigiado, por lá estar a Matriz e por ser o local de partida e chegada de procissões. Este prestígio é denotado pelo esmero de acabamento e detalhe das construções do largo. O lampião, visto em primeiro plano, engastado no canto da casa à direita, era de querosene. A grande torre quadrada da Catedral era marcante no Largo da Sé" (1979: 13).
\end{abstract}

\title{
Cartão 2
}

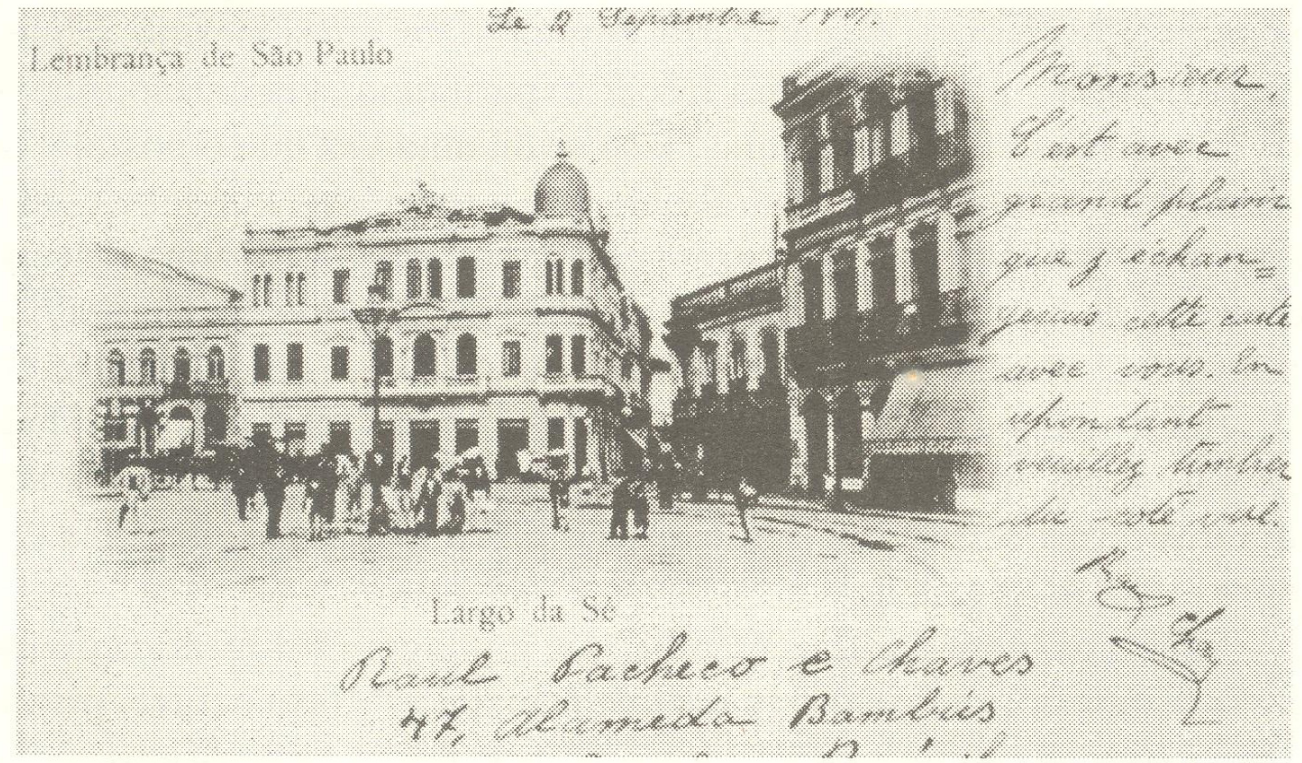

Segundo Monsenhor Jamil, eis aqui a primeira imagem cartográfica da Sé de que se tem notícia. Reprodução fotográfica impressa em tipográfica, este 
postal, mesmo tendo circulado em 1901, provavelmente data de fins do XIX. Seu autor é Guilherme Gaensly, eminente fotógrafo suíço que se radicou em São Paulo abrindo, em 1898, com um sócio, a firma fotográfica "Gaensly \& Lindemann". Quando, em 1900, rompeu com Lindemann, abriu nova empresa, "G. Gaensly", e reeditou os cartões já produzidos anteriormente. O postal que vemos acima pertence a essa série relançada, o que se vê pela legenda presente no seu lado esquerdo, que não conta com a referência "Lindemann", presente na razão social da empresa anterior de Gaensly.

O seu modelo segue o padrão dos primeiros postais existentes: uma face se destina exclusivamente à indicação dos dados do destinatário, enquanto a outra, que vemos aqui, contém, ao lado da imagem tipo "vinheta", um espaço vazio para a mensagem escrita.

Um primeiro olhar sobre o cartão revela aspectos interessantes do seu uso naquele contexto específico que era a São Paulo da "virada"; mais especificamente, a cidade por volta do "2 Septembre 1901". Ao lado da imagem do Largo da Sé, tirada a partir da esquina da Rua Venceslau Brás em direção às ruas Direita e XV de Novembro ${ }^{14}$ o pequeno texto do remetente, Raul Pacheco Chaves, eminente representante das elites paulistanas:

"Monsieur,

C'est avec grand plaisir que j'échangerais cette carte avec vous. En repondant veuillez timbrer du côté vue [sic]"

Essa mensagem deixa claro que o uso do objeto cartão transcende a simples função de ser um meio de correspondência entre as pessoas de lugares distantes. Ele aparece, ao contrário, como um fim em si mesmo: o que vale é se corresponder, não tanto para trocar experiências via cartão, mas mais para trocar cartões via experiências. Isso se dá uma vez que o postal é capaz de transmitir sinteticamente os símbolos que o remetente concebe como importantes para garantir que um estrangeiro (francês) guarde uma determinada impressão de São Paulo: a vista do edifício da "Pharmacia Baruel", branco e imponente em estilo eclético à frente, enquanto a outra esquina com a Rua Direita destaca o Café Girondino, um dos locais mais agitados da cidade naquela época. Além disso, burburinho "cosmopolita": gente que se movimenta em torno de um dos famosos lampiões a gás que, naquela época, ainda prevalecem na cidade ${ }^{15}$.

Sabemos, com Barthes (1990), que a imagem fotográfica do cartão veicula imagens por meio dos signos que transmite ${ }^{16}$. Isso ocorre, primordialmente - como diz Leite (1993) - a partir de espaços geográficos, pois que estes revelam códigos e valores sociais profundamente enraizados no contexto cultural no qual a fotografia surgiu. No caso deste cartão, qual a imagem de cidade expressa? A meu ver, a primeira imagem que passa é a de uma cida- 
de "moderna" porque dotada de edifícios não mais coloniais, um café e lampiões. No entanto, o propriamente "colonial" insiste em aparecer. Santos Jr., por exemplo, demonstra isso ao descrever do ponto de vista arquitetônico os principais edifícios do Largo desse momento: são "construções que no afã de se modernizarem buscam esconder a feição tradicional através de elementos variados agregados a sua fachada, como a balaustrada que aparece na platibanda do prédio do Café Girondino" (1991: 43). Além disso, pode-se destacar a presença de carroças e tílburis, produtos ainda do século XIX, uma vez que o Largo é nesse momento, como dizem Miyazaki et alii (1979), o estacionamento primordial desses meios de transporte, na cidade.

Há um outro aspecto interessante de ser assinalado, relativo à simbologia presente nos dois edifícios destacados na imagem. Os dois prédios são uma pharmacia e um café. O primeiro fala de salubridade, higiene, duas das palavras-chave que permeavam o imaginário das elites paulistanas na virada do século ${ }^{17}$; o segundo, um estabelecimento essencialmente urbano, revela o lado cosmopolita da cidade. Ambos compõem, desta forma, a moldura simbólica pela qual a cidade deve ser vista à distância: como símbolo de "ordem" e "progresso".

Gostaria ainda de ressaltar um fato curioso. A indicação do endereço do remetente, que ele faz questão de incluir no cartão, aparece seguindo o modelo francês e inglês: o número da casa ("47") aparece antes do nome da rua ("Alameda Bambús"). Se levarmos em conta que hoje em dia o modelo é diferente (a indicação do número da casa vem à direita do número da rua), esse pequeno detalhe aparentemente burocrático ganha relevo, pois revela que a proximidade que as elites procuravam estabelecer naquela época com o universo cultural europeu passa até por coisas aparentemente banais, como a identificação do próprio endereço residencial. 


\section{CARTÃo 3}

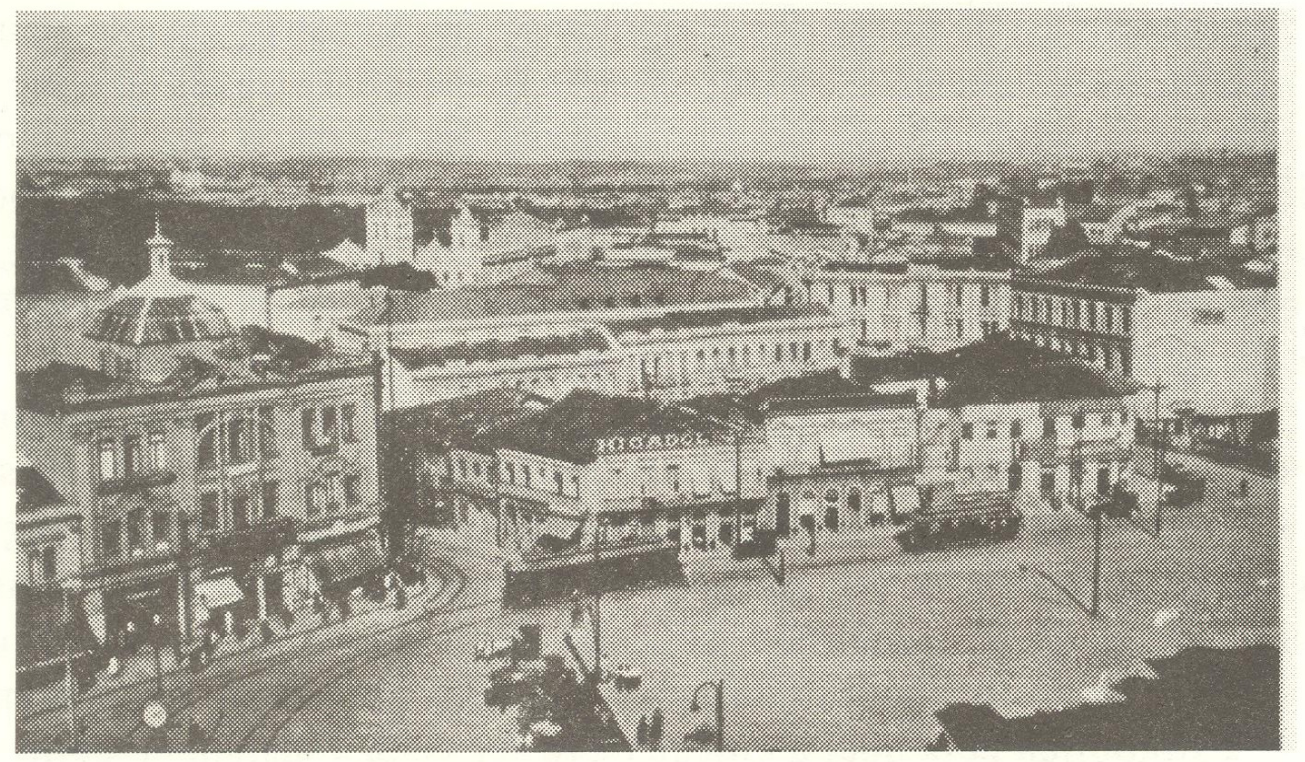

De novo o Largo da Sé, desta vez num momento em que o cenário já se compõe de bondes, trilhos, relógios, edifícios. O cartão é só imagem. A "mensagem lingüística"18 se compõe dos dizeres “(9) Brasil - São Paulo - Largo da Sé”. O número entre parênteses diz respeito, provavelmente, à classificação do cartão dentro de uma determinada série produzida com a temática presente na fotografia. Como no primeiro cartão da amostra, trata-se aqui de situar o Largo na cidade que o abriga. A diferença reside no fato de que, contrariamente aos dois cartões anteriores, é também fundamental situar a cidade no seu país - "Brasil". Assim, aparece um padrão de indicação que se perpetua até hoje nos postais com cenas urbanas.

Não há qualquer referência explícita à data de produção do cartão. Com base em alguns dados históricos referentes ao espaço focalizado pela câmera, sabemos que se trata de um momento posterior a 1912, momento em que a antiga Matriz foi demolida. Afinal, a fotografia foi tirada provavelmente de um prédio situado na esquina entre o Largo e a rua Direita - talvez o último andar da "Pharmacia Baruel"? - em direção à rua Venceslau Brás (antiga Travessa da Sé), tendo as torres das duas igrejas do Carmo (a da Ordem Primeira e Terceira) ao fundo $^{19}$. O grande espaço não construído que domina a metade inferior da imagem é o vácuo deixado pela demolição da antiga Matriz e dos quarteirões que a separavam do Largo de São Gonçalo (atual local da Praça João Mendes).

Poder-se-ia pensar também nos cartazes de publicidade que aparecem na imagem como outro parâmetro interessante de datação dos cartões. No caso deste cartão, dentre os vários cartazes presentes na imagem - "Higadol", "Caxambu", "La Reine", "Elixir Prata" - foi-me possível encontrar as datas de surgimento dos 
painéis da água "Caxambu" - 1904-1905 - e do produto "La Reine", "o cigarro chic!" (Abril Cultural, 1980: 36), este introduzido no mercado entre 1918 e 1919. Das duas referências, esta última serve como parâmetro mais preciso, que deixa claro que a imagem data de um momento posterior a 1919.

Vejamos o que diz o parâmetro "invenções tecnológicas" sobre a data da imagem. No caso analisado aqui, destacam-se bondes elétricos - a primeira linha é inaugurada em 1900 - do tipo "camarão" (que aparece no centro da fotografia) e a "jardineira" (atrás dele); vários lampiões de luz elétrica (implantados na cidade a partir de 1899 pela São Paulo Tramway, Light \& Power Co.); automóveis - que chegam, em grande número, também nos primeiros anos do século (Bruno, 1954). Conta-nos Zareh Chouchanian, gerente da concessionária de vcículos antigos "Jardineira Veículos", que, se tomarmos como parâmetros os automóveis, a fotografia que vemos deve ter sido feita em algum momento entre 1923 e 1924. Como se sabe? Ela não pode ser anterior a 1920, uma vez que aparecem nela modelos Chevrolet e Ford "modelo T", produzidos nos primeiros anos da década de 1920. Também não pode ser posterior a meados dos 20 , uma vez que não aparecem automóveis Ford com modelos de 1925/26. Os Ford são um parâmetro fundamental por terem sido os veículos mais comumente utilizados como táxis na época, de forma que, se a imagem que vemos datasse de final da década de 1920, certamente apareceriam nela os Ford com os modelos do ano, principalmente retratando a fotografia o local de estacionamento mais conhecido da cidade, o Largo da Sé.

A imagem retratada apresenta, no primeiro Plano, um panorama da vida urbana no Largo da Sé. A profusão de ícones de modernidade e o vazio de pessoas parecem atestar: o Largo "pertence" aos bondes que o percorrem, aos lampiões elétricos que o iluminam, aos automóveis que nele estacionam. No canto esquerdo embaixo aparece o símbolo máximo daquilo que o sociólogo Henri Lefebvre (1986) chama de "tempo linear" e que caracteriza o ritmo da vida cotidiana "moderna": o relógio. Este possui três faces, já substituindo "o lampião na demarcação do espaço" (Santos Jr., 1991: 16). Talvez por se tratar de uma manhã de sol, o relógio do Largo assinala: 11 horas e 10 minutos... A partir do momento em que surge no cenário do Largo, este relógio permanece durante anos como ponto de encontro por excelência do local (Miyazaki et alii, 1979).

A impressão que se tem é que a "modernidade" paulistana do momento do cartão só pertence a poucos. Na verdade, os vários simbolos parecem ser os verdadeiros proprietários de todo esse ambiente aparentemente "moderno"... Afinal, é somente atrás das linhas de bonde, perto dos edifícios em estilo eclético de no máximo dois andares que cercam o Largo, que se aglomeram as pessoas. E não são muitas.

Em contraposição a todo esse panorama "moderno", a metade superior do cartão permite que se vejam os limites da cidade - e estes são coloniais. Enxergam-se as torres do Carmo, testemunhas do passado de villa da ci- 
dade, que se destacam por fazerem das duas igrejas os edifícios mais altos de toda a skyline, composta do verde das colinas, ao longe, e das muitas outras torres de igrejas. Elas aparecem ao lado de outros edifícios coloniais e da Várzea do Carmo, corredor que se entrepunha, nos primórdios da expansão da cidade novecentista, entre os bairros operários e a chamada colina histórica.

\section{Cartão $4^{*}$}

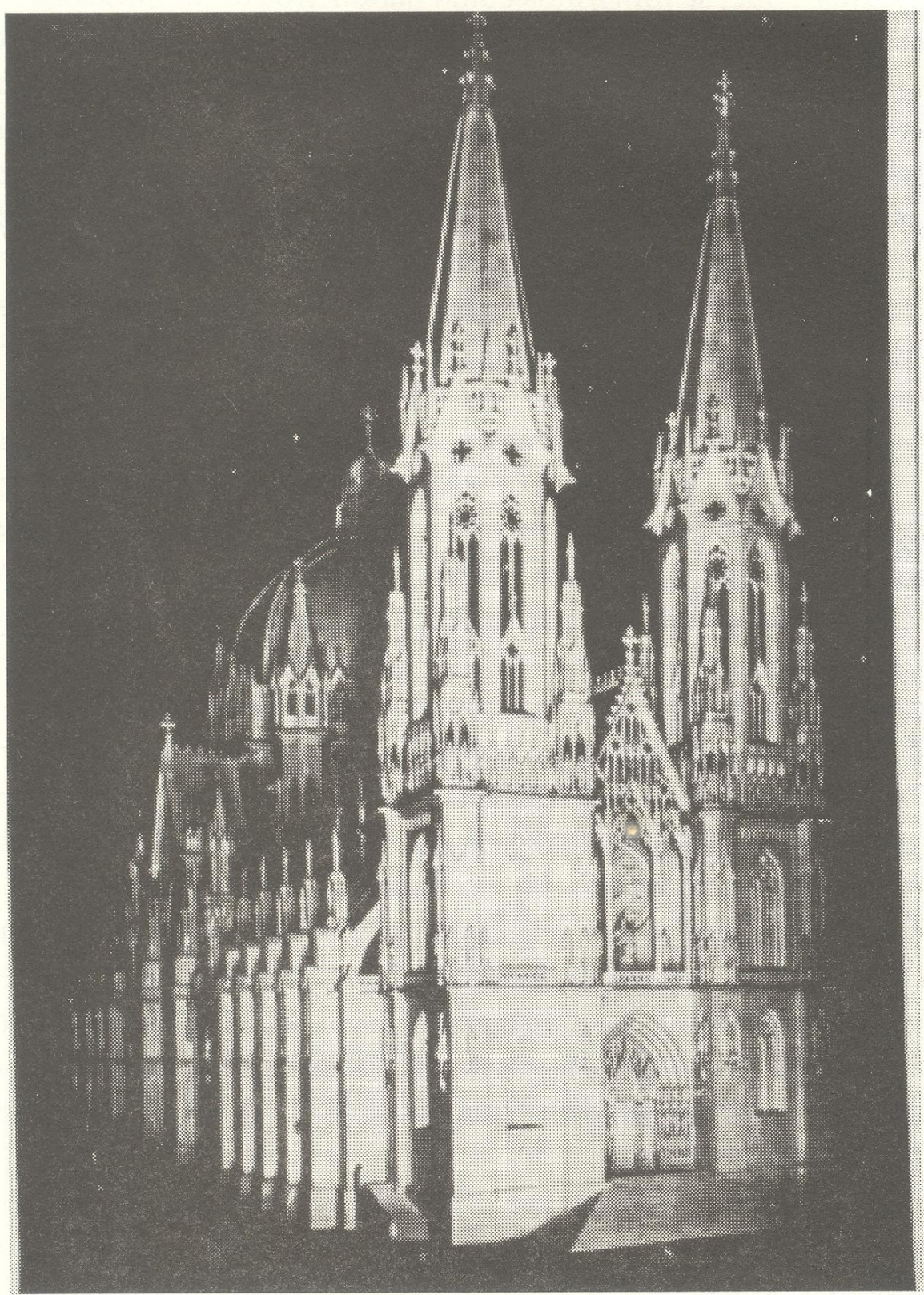


A legenda revela: "São Paulo - 22 - Catedral da Sé”. Trata-se do $22^{\circ}$ cartão de uma série de imagens feitas, segundo Monsenhor Jamil, pelo fotógrafo G. Prugner (vem daí as iniciais "G.P.") provavelmente um pouco depois da Revolução de 1924, em São Paulo. Pode-se deduzir isso, conta-nos Jamil, devido ao fato de que Prugner foi um fotógrafo que começou a editar seus cartões no período da Revolução. Esta imagem que vemos deve ser um pouco posterior a esse acontecimento, portanto.

No cartão, a "mensagem literal" se constitui de um objeto: a maquete da nova "Cathedral da Sé", projetada para o antigo Largo da Sé depois de 1913, depois que o projeto de Max Hehl está concluído e passa a se inscrever no espaço físico da cidade. A aparência reluzente da figura, que se deve ao forte clarão produzido pelo fotógrafo ao bater a fotografia, evoca a impressão de que o templo é dourado.

Retratando aquilo que ainda nem existe concretamente, mas que deve ser veiculado enquanto projeto abstrato que é, este cartão tem o caráter de mediação que se coloca entre a abstração possível da promessa e a impossibilidade concreta do fato. Ou seja, vai de encontro à ânsia dos criadores e divulgadores dos cartões postais paulistanos de propagar, por meio de símbolos utópicos - já que todavia sem lugar no espaço físico da cidade - a promessa do progresso e da magnitude da Paulicéia, que a Catedral realizará no antigo Largo da Sé tão logo a maquete se torne realidade.

E isso tudo exatamente porque, naquele mesmo momento, a Catedral ainda não é mais que uma maquete, fazendo do Largo um grande espaço aberto onde se degladiam o pó das construções, os bondes, os automóveis e fica o vazio: vazio de construção, vazio de história, vazio de sentido...

\section{Cartão $5^{*}$}

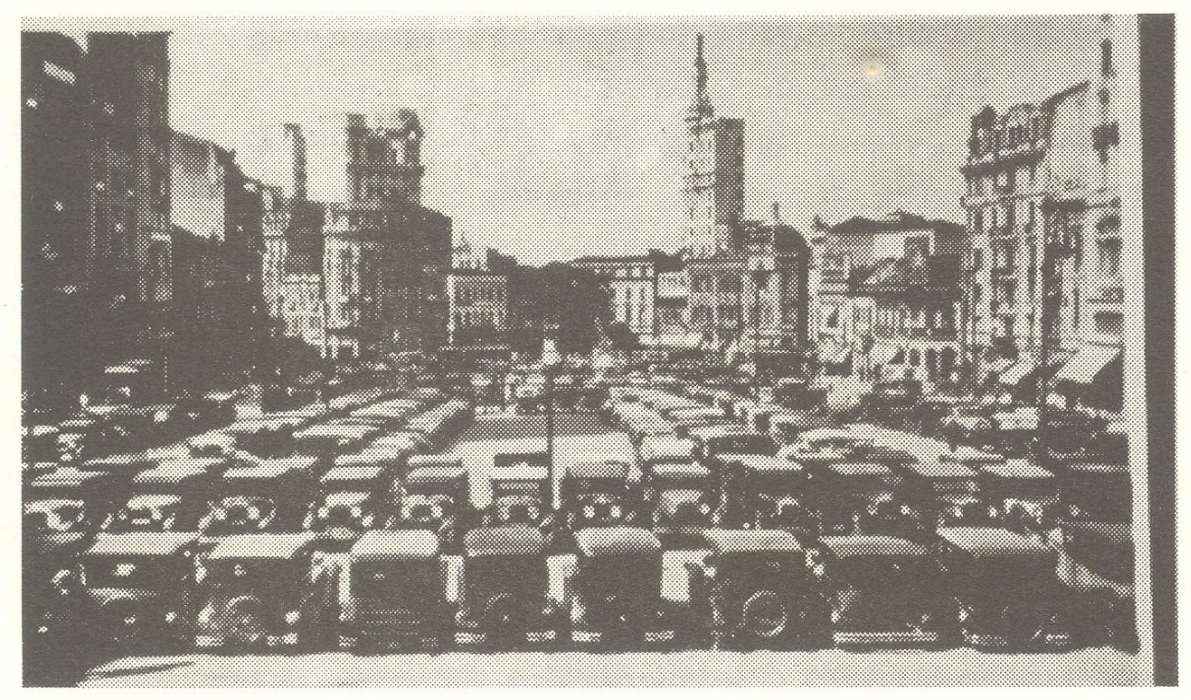


Eis aqui uma vista da "Praça da Sé" - e não mais "Largo" - em toda a extensão que adquiriu após a demolição tanto da antiga Matriz quanto dos três quarteirões já mencionados anteriormente. A fotografia contempla as ruas Direita, XV de Novembro, Floriano Peixoto e Venceslau Brás a partir dos degraus da escadaria daquilo que mais tarde seria a Catedral ${ }^{20}$. A perspectiva é facilmente dedutível pelo fato do ângulo de visão do fotógrafo aparentemente se situar acima dos carros, de forma que se vêem, em primeiro plano, os tetos dos veículos situados no imenso vazio que é a Praça.

Os automóveis presentes na cena são os parâmetros fundamentais para a datação da imagem. Diz o especialista da "Jardineira": deve-se tratar de um momento entre 1929 e 1930, já que já aparecem os famosos "Ford 29 - Ford Bigode", facilmente reconhecíveis pelos pára-choques (como é o caso do quinto e do sexto carros da esquerda para a direita, no primeiro plano da fotografia).

O que mais impressiona na imagem é o ângulo a partir do qual ela foi feita: o fotógrafo se posta de costas à Catedral. Isso se dá porque a construção do prédio está em seu início. Mais vale destacar a enorme quantidade de símbolos de progresso que a Praça já abriga. Ela é só automóveis - táxis, em sua grande maioria, uma vez que os automóveis eram caros e só poucos os possuíam particularmente - que dominam a Praça estacionados de forma absolutamente ordenada e simétri$\mathrm{ca}^{21}$. Enquanto aqueles paralelos ao olhar do fotógrafo "olham" para fora do coração do Largo, os situados perpendicularmente a este estão voltados para o centro do local. Estranho arranjo: "ordem e progresso" paulistanos...

Em contraposição a tanta máquina, pouca gente. O elemento humano está praticamente ausente: vê-se só um transeunte solitário no canto esquerdo inferior do cartão. Indivíduo moderno, criador impávido que reina soberano ao lado da sua criatura maior, o automóvel? Independentemente se o objetivo do fotógrafo tenha sido o de celebrar a "modernidade burguesa" exaltando as suas duas instâncias maiores - o indivíduo e a máquina, sujeito e objeto -, o fato é que a imagem contribui para ressaltar o lado "moderno" e "amplo" da Praça da Sé e, por conseguinte, de São Paulo. Já que as bases da Cátedral ainda estão sendo erigidas, vale focalizar o outro lado, veicular no cartão aquilo que deve ser visto porque ë assim que São Paulo - mais especificamente os seus fotógrafos, geralmente membros das elites - se $v \hat{e}^{22}$.

Em volta dos carros, vários edifícios compõem a skyline como monumentos absolutos do "progresso": tanto pela sua altura, que desafia os limites da técnica ${ }^{23}$, - o edifício conhecido como "Garrafa", ao fundo, na esquina com a rua Floriano Peixoto, se destaca por ter dez andares -, quanto por seu estilo arquitetônico - o ecletismo, que, como nos conta Julião, é produto da "burguesia ascendente" e corporifica a "exaltação das conquistas do progresso, pois assimilava e exibia as inovações tecnológicas (...) citando padrões arquitetônicos remotos" (1992:28). 
O interessante é que, mesmo que prevaleçam os edifícios ditos "modernos", ainda existem muitos os quais se pode reconhecer, após observação mais detida, como sendo antigas casas coloniais, produtos de outros tempos, que tiveram as suas fachadas modificadas para a colocação ou não de painéis publicitários...

\section{Cartão 6}

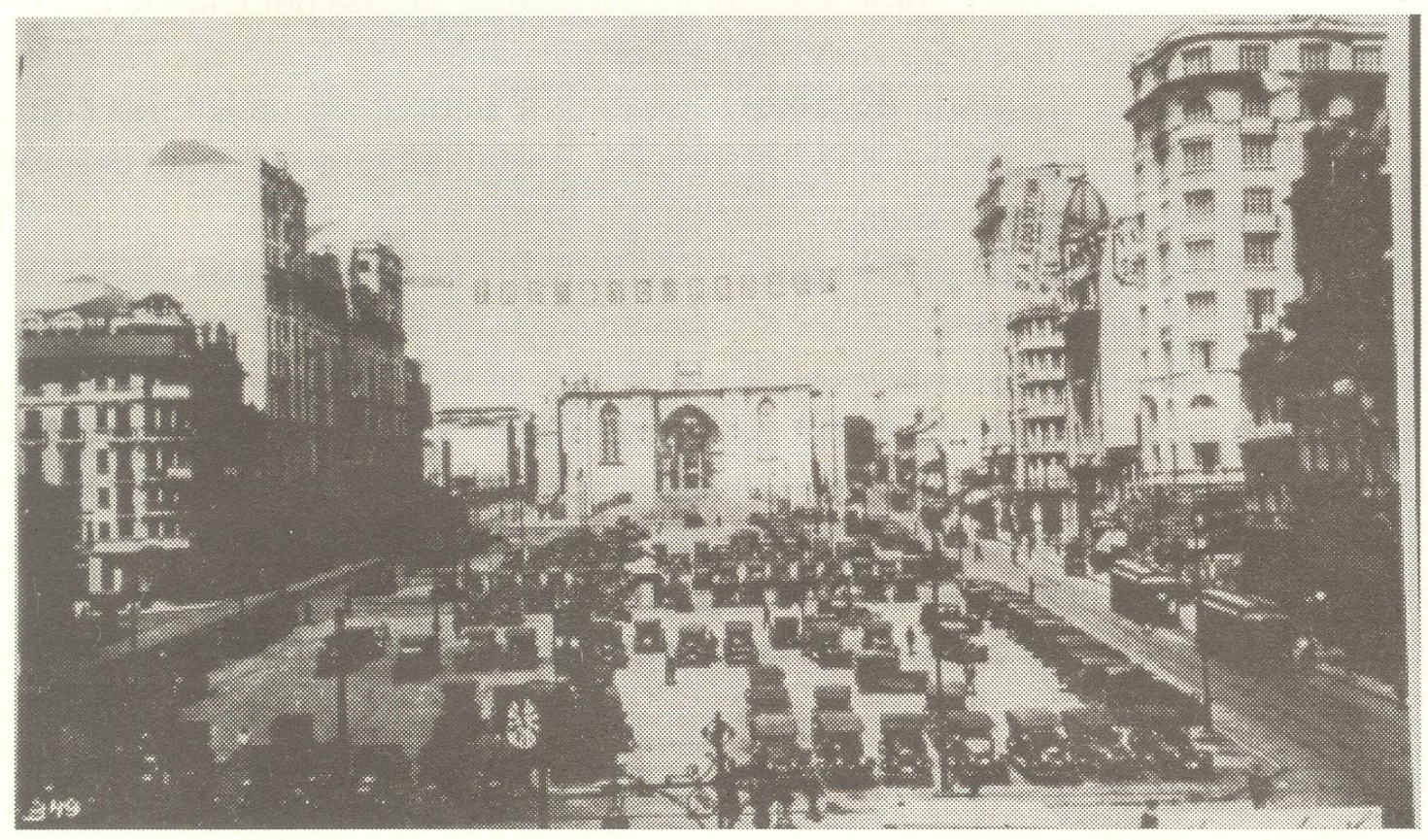

Neste cartão aparecem, segundo Chouchanian, tanto automóveis mais antigos (produzidos entre 1924 e 1926) no plano inferior da fotografia quanto outros mais "modernos", de 1927 a 1929. Eis a moldura temporal que permite afirmar: anos 20. E intuir a conjunção de temporalidades distintas mas crescentemente contraídas que perfazem os "tempos modernos", de modo a tornar passado e futuro instâncias secundárias, uma vez que, cada vez mais, deformados para caberem na única fôrma válida: o instante, o presente...

Peculiar aqui é a perspectiva de enquadramento da fotografia. Eis um momento em que o fotógrafo se volta frontalmente para a Catedral, dando as costas para as ruas que antes focalizava, e que vimos no cartão anterior ${ }^{24}$. Parece que agora há o que mostrar: afinal, parte substantiva da Catedral foi concretizada; do lado esquerdo, regem, imponentes em pas de deux o Palacete Santa Helena, inaugurado em 1922, e o edifício Mendes Caldeira; do lado direito da Praça, outros grandes edifícios de aproximadamente dez andares cada, que superam em altura as dimensões da própria Catedral - por enquanto... 
Curioso é perceber que essa muralha de prédios parece cercar exclusivamente a área da Praça; mais ao fundo, para além dos edifícios que circundam o local, todas as construções ainda são baixas, possuindo no máximo três andares. Eis um aspecto interessante que revela a estratégia pontual da especulação imobiliária: existem alguns pontos valorizados na cidade, como a Praça da Sé, e é neles que se concentram todos os investimentos arquitetônicos. Naquele momento, toda a região mais ao sul da Praça, em direção à estrada do Vergueiro, ainda é considerada longínqua, interiorana, como atestam as fotografias tiradas por Claude LéviStrauss em sua época de estadia em São Paulo ${ }^{25}$.

Destaca-se, um pouco acima das bases da Catedral, a grande faixa com os dizeres "O Grande Desfile - The Big Parade". Entretanto não consegui descobrir de que comemoração se trata.

A Praça continua sendo o palco privilegiado dos automóveis, dessa vez mais ordenados que no cartão anterior. Disputam o primeiro plano da imagem com vários outros símbolos de modernidade: um ônibus, um lampião elétrico característico da Light e o já conhecido relógio de três faces. São Paulo como sede do "moderno", encarnado nos avanços tecnológicos, nas invenções, na máquina....

Frente a toda essa profusão de objetos, a escala humana desaparece, fica sem lugar. E é bom que assim seja, pois o quc São Paulo deve apresentar ao mundo não é o seu caráter propriamente humano, mas sim a sua potência material.

\section{CARTÃo 7}

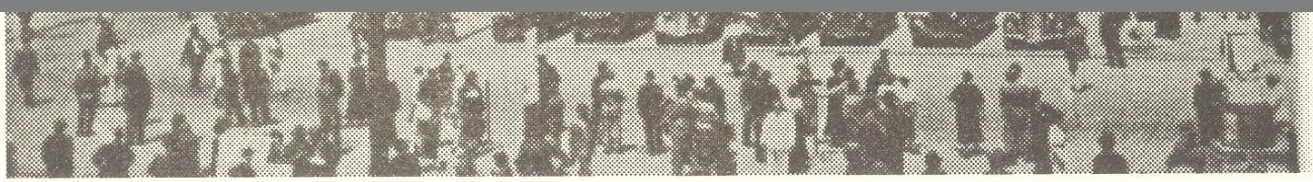


Neste novo momento da Catedral da Sé, de novo a Praça, retratada pela Fotopostal, laboratório de fotografias que apareceu no cenário paulistano na década de 1930. Trata-se aqui de uma imagem da São Paulo de meados da década de 1930, momento em que já há os automóveis Packard (produzidos em 1935/1936), os novos modelos Ford com as características grades do radiador; os Mercedes Benz com suas estrelas nos capôs, que caíam sempre...

Amparada à esquerda pelo Palacete Santa Helena e o Edifício Mendes Caldeira, a Catedral cresce lentamente ${ }^{26}$. E se torna nome de produto anunciado em propaganda no relógio da Praça: "REMÉDIOS VEGETAES CATEDRAL".

Aliás, neste cartão escancaram-se os novos usos de vários dos símbolos de modernidade que vêm acompanhando a história da Praça e das imagens dos cartões desde o início deste século. Primeiramente, percebe-se a presença de cartazes e placas de publicidade em todos os edifícios da fotografia com exceção da Catedral, por questões óbvias. Assim, esses prédios tornam-se, eles mesmos, espaços cercados pelas muralhas que os grandes painéis de "Cito", "Parquetina", "Emulsão de Scott", "Casa Dragão" representam.

Além disso, há o novo aspecto do já tradicional relógio da Praça. Também ele aparece tomado por publicidade, adquirindo a função de poste publicitário ao lado dos já tradicionais papéis de ponto de encontro e de marcador de tempo... Vê-se, assim, que tais elementos, produzidos para propagar a magnitude de uma época que vive da fragmentação dos indivíduos, acabam por serem vítimas dessa mesma fragmentação pois que até a sua existência, que se deve à sua funcionalidade, se divide entre várias frações de utilidade...

E entretanto, testemunhos de um outro tempo ainda insistem em transparecer por debaixo dos painéis ou da arquitetura eclética de fachada. Os dois edifícios de dois andares ao lado do Instituto Moderno próximos à esquina da Praça com a Rua Santa Tereza falam de um momento anterior a todo o presente que a Sé vive agora, mas que, exatamente por ter existido, fez com que a Sé se tornasse isso que é neste momento. Permanecem no cenário como resíduos que, corporificando o que não é - pois que aparentemente não-"moderno" -, anunciam o que pode ser: uma outra hisiória, na qual não fique relegada ao passado o lugar de suporte do passageiro, supérfluo, fugaz...

À frente da Catedral, a Praça traz uma novidade: uma parada de ônibus coberta, construção que institucionaliza a função do local como ponto de entroncamento do transporte público na cidade. O local todo aparece como palco no qual os mais diversos meios de transporte se degladiam. Ônibus, táxis, veículos particulares e bondes esquadrinham o espaço, e ao pedestre resta circular entre um transporte e outro. Tudo isso leva a que prevaleça, nesta imagem, a impressão de desordem: os carros não estão estacionados de forma absolutamente simétrica e organizada, os pedestres do primeiro plano 
esperam, lêem, olham, passam. O clima é, portanto, o de uma metrópole "moderna": São Paulo é a imagem da vida urbana com todas as suas características típicas de "multidão", trânsito", "caos"...

\section{Cartão 8}

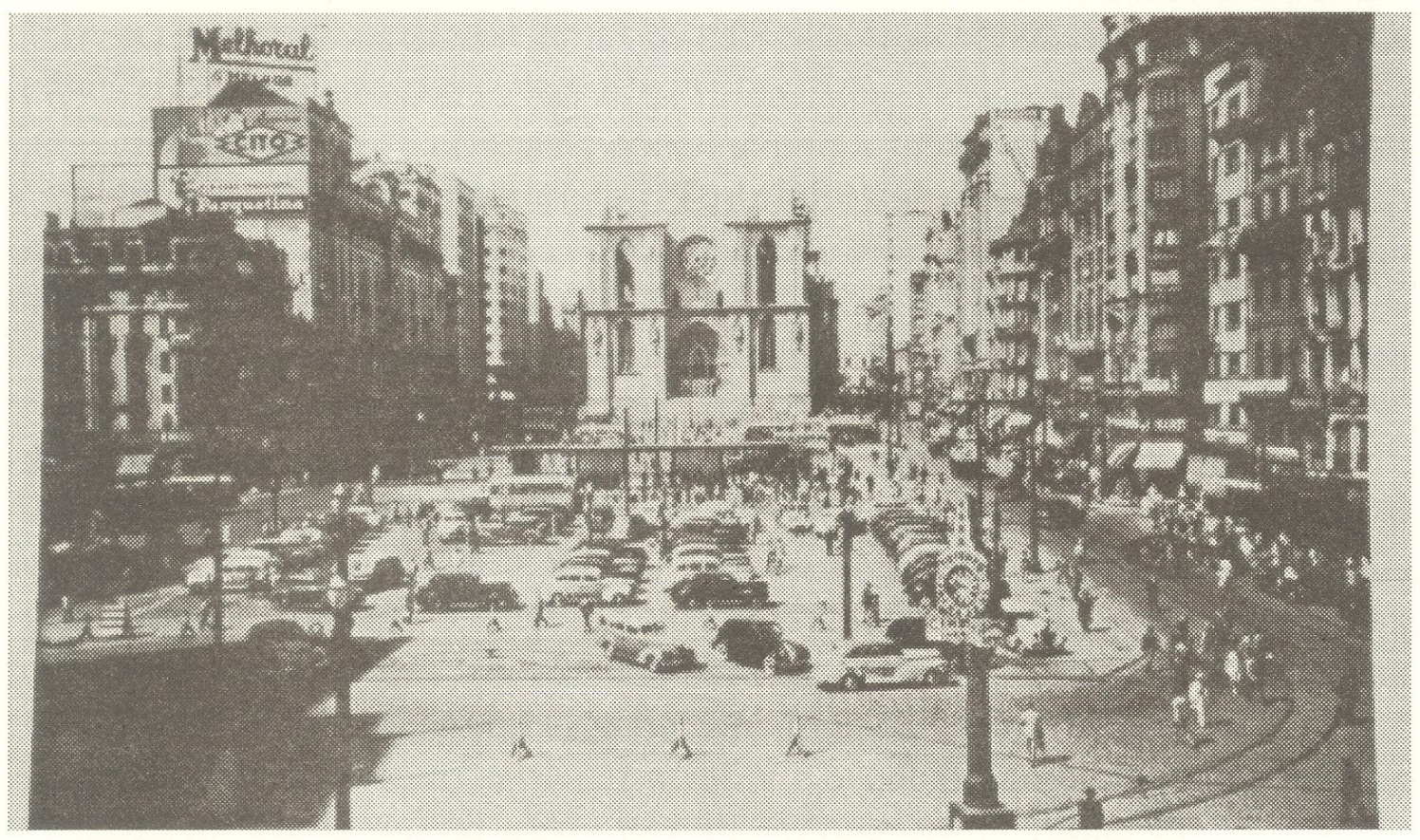

Novo cartão, sem qualquer legenda, que data dos anos 40. Provavelmente, conta Chouchanian, trata-se de anos anteriores ou os próprios 1946/1947, pois que o modelo mais "novo" de automóvel que aparece é o de um Citröen produzido entre 1947 e 1948. De resto, prevalecem os modelos surgidos no início da década, uma vez que, durante e logo após a Segunda Guerra Mundial, as empresas americanas e européias de automóveis deixaram de produzir novos veículos a fim de se dedicarem à produção de armamentos. Só aproximadamente em 1947 aparecem novos modelos.

Sem sombra de dúvida o centro do cartão ainda continua sendo a Catedral. Clara, limpa, ela se destaca frente aos outros edifícios da Praça, já todos meio escurecidos pelo tempo - uma estratégia do fotógrafo? A Catedral agora conta com o seu segundo grande pavimento concluído: já possui a aparência de templo religioso imponente, que se destaca em meio à muralha sempre crescente de edifícios que se erguem em volta da Praça. E com cada vez mais intensidade, ao fundo dela também. O único testemunho que resta do passado colonial da cidade transparece no fundo direito do cartão: a igreja de São Gonçalo, em frente ao antigo Largo de São Gonçalo. 
A Praça permanece marcada pela pluralidade de usos. Os pedestres continuam andando por entre e sobre os trilhos dos bondes; os carros - típicos do fim dos anos quarenta e início dos cinqüenta - continuam estacionados na Praça em frente à Catedral. O seu elemento mais característico, o relógio de três faces, mantém a função assumida no decorrer dos anos 30: é suporte de publicidade - desta vez da "Cama Patente Faixa Azul" e do "Vermuth (sic) Cinzano". Também volta a se destacar o Palacete Santa Helena. Agora não só as suas laterais, mas também e principalmente o seu telhado se torna local privilegiado para a divulgação propagandística de que "Melhoral é melhor"...

\section{Cartão 9}

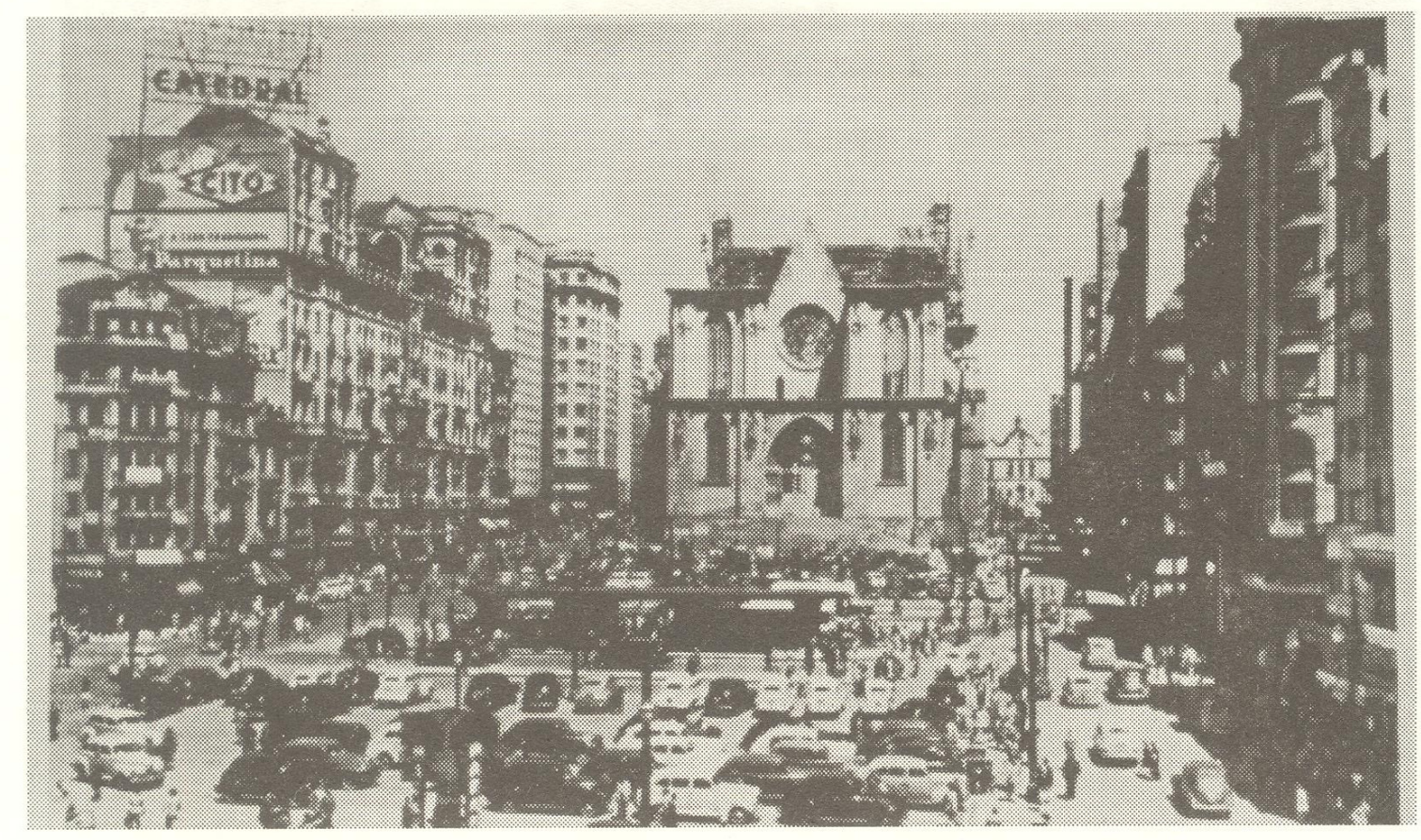

O tradicional enquadramento que já vimos no cartão 6. Dessa vez, tratase de um momento do final dos anos 40, já que não aparece nenhum automóvel da década de 1950, assegura Chouchanian.

A mudança com relação ao período do cartão anterior se faz perceptível também através do estado da construção da Catedral. Afinal, já começa a haver uma cúpula, fator que faz a Sé se igualar em altura finalmente aos mais altos prédios da Praça. Cercando o local de ambos os lados, os mesmos edifícios já presentes nas outras imagens. A diferença? Um novo painel publicitário domina o telhado do Palacete Santa Helena: dessa vez os "Medicamentos Vegetais Catedral", deixando de serem anunciados no poste do relógio, ganham as alturas da Praça. 
No plano inferior do cartão faz-se presente também e novamente o característico relógio; só que com nova e indecifrável propaganda ao seu redor.

A impressão que se tem ao observar o cartão é que em volta da Catedral em construção tudo é caos, trânsito e multidão. Por sua crescente altura, parece que a Catedral observa tudo, ao fundo, enquanto a vida pulula ao seu redor. A mensagem é uma só: a Praça da Sé é, definitivamente, o coração da Paulicéia. Sem sombra de dúvida, o lugar "onde tudo acontece" porque todos - do pedestre ao carro, passando pelo ônibus e o bonde - convivem lado a lado...

\section{Cartão 10}

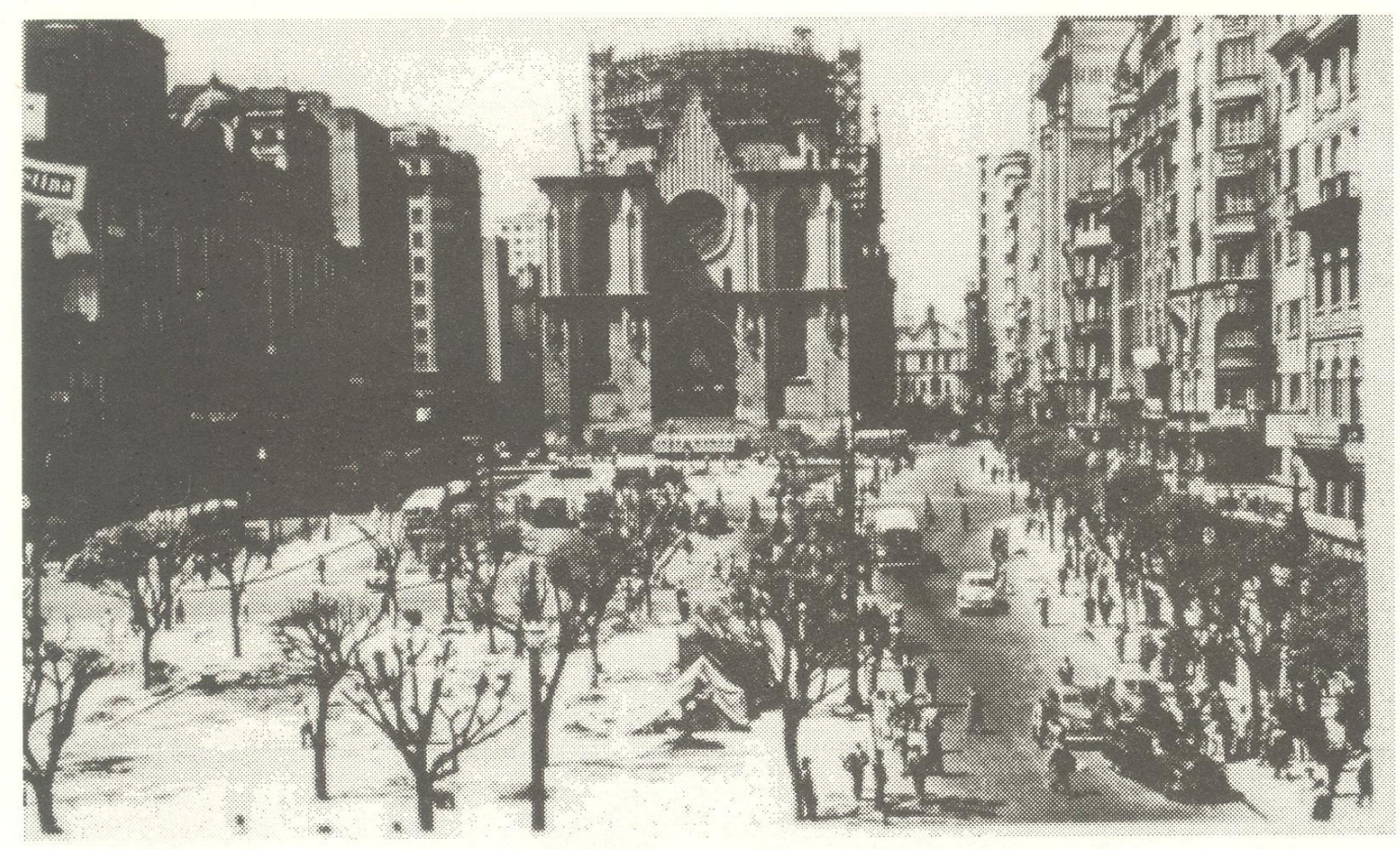

Uma imagem interessante. porque se nota que algo mudou na paisagem da Praça da Sé, além do fato da cúpula da Catedral já estar mais alta: pela primeira vez se vê árvores ocupando o espaço, ao lado de ruas delimitadas em contraposição ao espaço da Praça. A imagem data da primeira metade dos anos 50 , o que se reconhece através do primeiro e do terceiro carro (escondido) que se vêem no canto direito inferior da fotografia: respectivamente um Chevrolet $1951 \mathrm{e}$ um Chevrolet "Bel Air"de 1953.

Observando-se o cenário, reconhece-se que definitivamente o local deixou de ser largo para se tornar praça, que segmenta locais em que só pedestres devem pisar - e que, além de tudo, são arborizados - de outros em que os automóveis e ônibus - os trilhos de bonde desapareceram - predominam. Conforme conta Santos Jr., essa 
reforma de 1952 na Praça "definiu uma área para a circulação de pedestres e foram instalados abrigos com espaços intermediários para a passagem de ônibus" (1991: 121). Esse planejamento da Praça diz respeito aos preparativos do Quarto Centenário da cidade, em 1954. Parece que, pela primeira vez, surge a intenção de transformar a Praça num local de permanência de pessoas; e não de simples passagem. Percebe-se isso pelo fato de que o trânsito de automóveis diminuiu, o terminal de ônibus foi implantado na frente da Catedral, atrás das árvores.

Frente a todo esse cenário, a impressão é que se quer "abrir alas" para a inauguração da Catedral. Diminuir o trânsito de carros e ônibus - os quais, mesmo continuando símbolos de "progresso" e "civilização", passam a ter seus locais de passagem repensados - e plantar árvores significa transformar a Praça num local mais agradável de se estar e coloca a Catedral em primeiro plano de importância no cenário...

\section{Cartão 11}

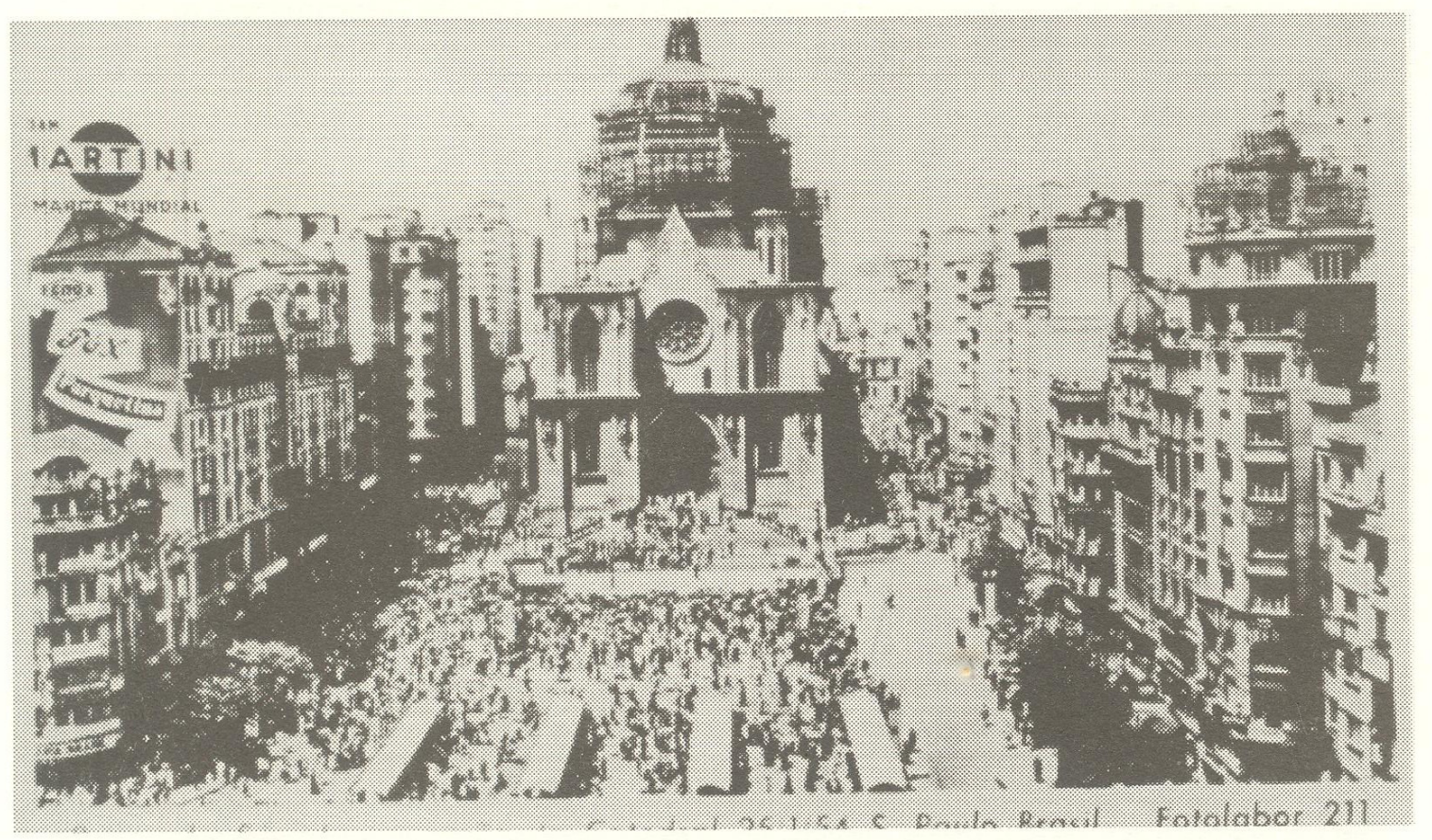

É interessante que, mesmo que pouco tempo antes das comemorações do Quarto Centenário, a Praça tenha sido remodelada, a fim de receber árvores e dispensar terminais de ônibus e o grande tráfego, ela aparece, neste cartão da Fotolabor - empresa criada no começo da década de 1950 -, com uma aparência bastante distinta do panorama visto na imagem anterior. Trata-se de um novo ângulo para apreender a já tradicional vista da Praça. Neste caso, uma fotografia aérea para dar 
conta da Sé em toda a sua extensão - da base à cúpula conclusa - tirada a partir do edifício da Caixa Econômica Federal, este construído durante 1934 e 1938 no local em que antes havia o Instituto Moderno. Assim, as árvores estão fora do cenário fotografado: estão situadas mais abaixo, fora do ângulo focalizado pelo fotógrafo, em favor da presença da parte superior da Praça, onde há, desde a reforma, quatro amplas paradas de ônibus.

Esta é uma primeira vista da Praça onde esta aparece tomada por gente, ponto em que, por ocasião das comemorações do Quarto Centenário e de inauguração da Catedral, as pessoas se concentram. O templo é aberto ao público, sem que o seu projeto original - retratado na maquete-cartão - tenha sido concluído de fato. A cúpula principal está pronta, mas não se encontra todavia livre dos andaimes de sustentação.

No momento em que a Praça chega ao quarto centenário da cidade e a Catedral, eis que ganha sentido resumir a imagem deste cartão por meio de uma palavra que sintetize a dinâmica paulistana: metamorfose. Tudo muda nessa Praça que é o símbolo de São Paulo. Da publicidade no topo do Edifício Santa Helena aos novos prédios construídos na metade superior do cartão, ao lado da Catedral; dos pontos de ônibus às árvores: "tudo que é sólido desmancha no ar"...

\section{Cartão 12}

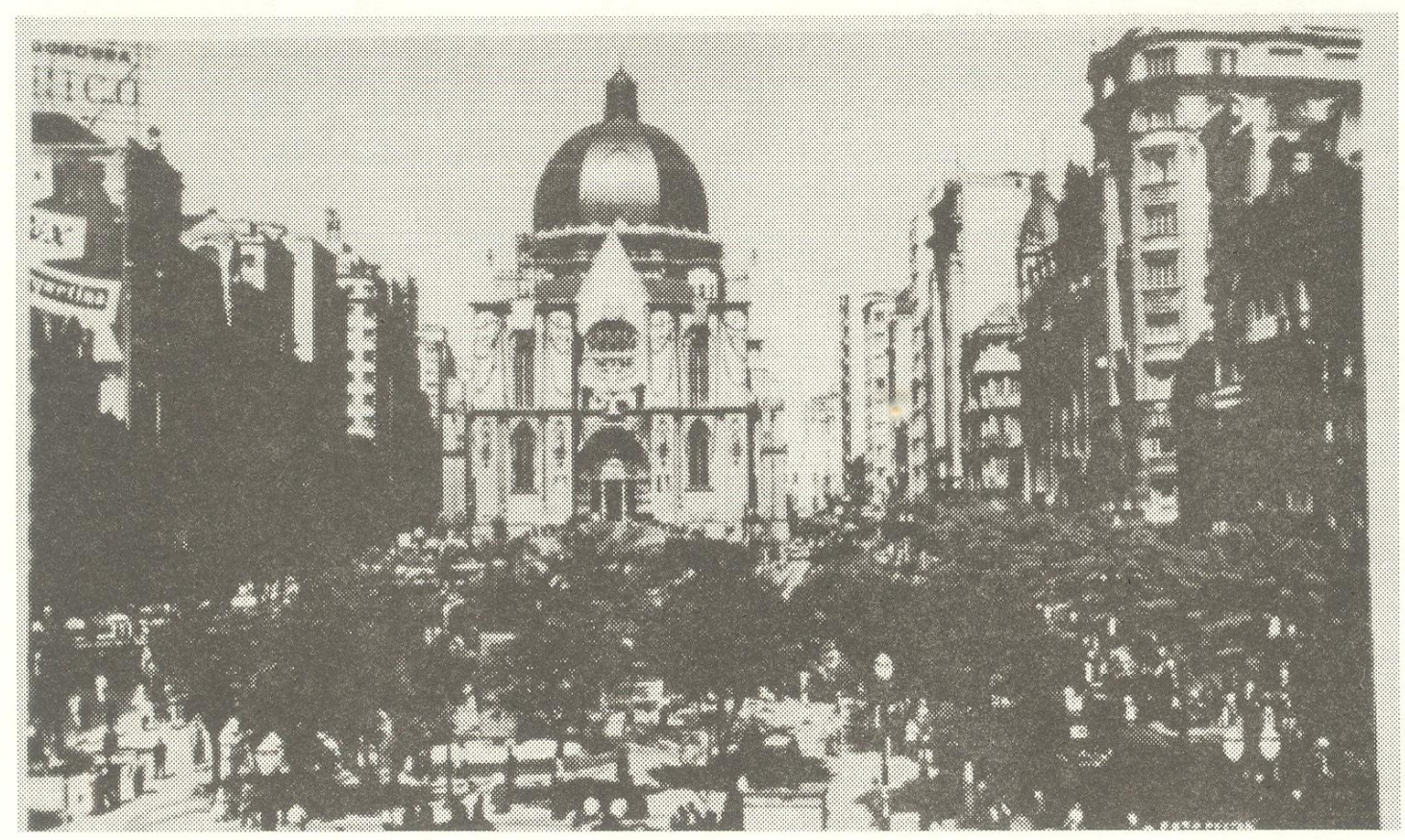

No momento em que a Catedral já não necessita mais dos andaimes de sustentação da cúpula, eis que a paisagem da Praça novamente se encontra modi- 
ficada. Vêem-se, em primeiro plano, as árvores já maiores, os bancos... A concepção de "praça" que se tem nas cidades do interior? Por entre as árvores, desponta, em segundo plano, a estátua de José de Anchieta, monumento incorporado ao cenário com as comemorações do Quarto Centenário. Ao alto, no centro, a Catedral, cujos muros se encontram enfeitados com bandeiras do Estado de São Paulo e guirlandas. Dia de comemoração na cidade...

Impressiona, nesta imagem, a conjugação que o fotógrafo conseguiu fazer entre elementos aparentemente antagônicos, o que passa a curiosa idéia de que São Paulo integra "campo e cidade". Observando a metade inferior da fotografia, vê-se pouco trânsito de carros, em contraposição a um movimento mais intenso de pessoas, que parecem fruir pacificamente do espaço da Praça. Tanto que os pontos de ônibus não aparecem. Neste fragmento de imagem, portanto, a impressão de São Paulo transmitida ao observador é de "pacatez" e "tranqüilidade" interioranas. A outra metade da fotografia, ao contrário, remete a uma atmosfera profundamente "urbana", seja pela existência da publicidade no topo do Santa Helena, pelas dimensões da Catedral ou pelo tamanho dos prédios que circundam a Praça e os seus fundos: arranha-céus metropolitanos...

Canta o poeta baiano: "São Paulo é como o mundo todo". Mundo em que se convivem campo e cidade, pacatez e cosmopolitismo, natureza e cultura?...

\section{Cartão 13}

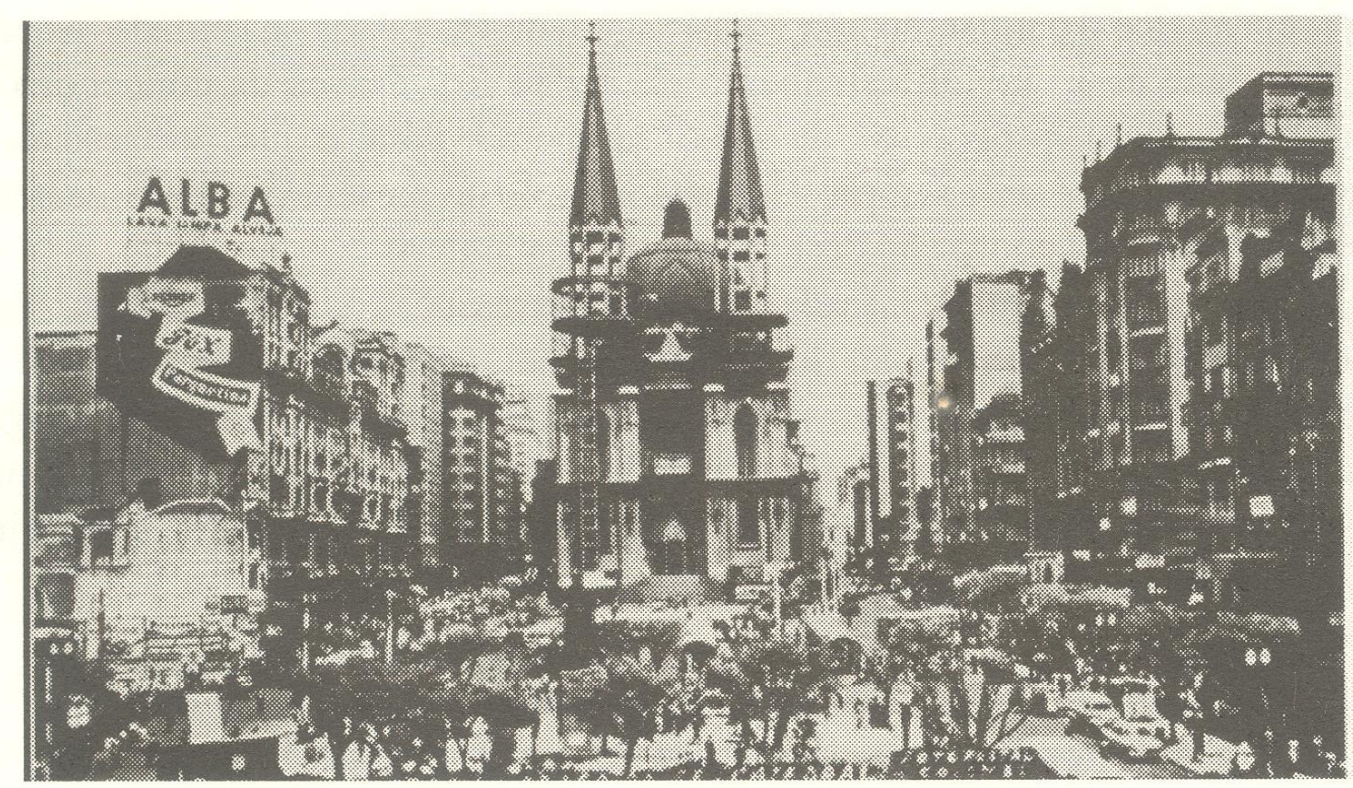

Essa imagem data possivelmente de meados da década de 1960. Destaca-se nela o fato de que já existe, ao centro, a Catedral da Sé com suas duas torres 
quase concluídas ${ }^{27}$. A Praça mantém sua parte frontal arborizada e o terminal de ônibus ao fundo. Entretanto, há menos árvores, o que antecipa, de alguma forma, os desenvolvimentos futuros do local, a partir de 1971, para a construção da estação central de metrô.

Circundando a Praça lateralmente, continuam os - a essa altura já "antigos" - prédios do início do século. Não só circundam, mas sim protegem por sua altura, que se estende até a skyline, ao fundo. Ao lado do Santa Helena, coberto por "Alba", que "lava, limpa, alveja", instaura-se um vazio: derrubou-se o edifício Mendes Caldeira, vizinho ao Palacete. e utliza-se a lateral deste nara afixar

nário, eis que volta um cartão tão "frenético" quanto São Paulo. A razão para isso advém talvez do forte contraste de claro e escuro que surge da contraposição do concreto armado do pavimento da Praça e dos novos edifícios situados atrás da Catedral, junto à tonalidade clara dos carros com o já cinza dos prédios mais velhos que rodeiam o local.

\section{Algumas Reflexões}

Procurar os percursos da Sé nos cartões revelou-se uma viagem fascinante pelo passado recente da cidade - mas que já parece tão antigo... O que evoca essa impressão? As transformações espaciais bruscas e constantes por que a cidade e sua "praça cívica" passaram nos últimos cem anos e que se incorporaram ao tipo de percepção que o paulistano tem da passagem do tempo, na sua cidade. Aceitar a efemeridade do estar em detrimento do ser se faz através da concepção da inexorabilidade do "progresso", de que o "tempo não pára" e que, portanto, deve ser gozado como presente sempre. Essa valorização do presente em detrimento do passado depende da contração deste naquele, dilatando-o.

Essa corrida interminável rumo ao "progresso", à “civilização", ao "moderno" se reflete na construção do espaço. Afinal, desencadeia no paulistano a ansiedade de criar sempre o novo só por sua característica de ser novo e estrangeiro, pouco importando se ele é de pior qualidade e incompatível com aquilo que antes ocupava o espaço físico da cidade. Eis o que dá sentido ao comentário do escritor António de Alcântara Machado sobre a Sé:

\footnotetext{
"a preocupação dos governantes e governados é derrubar para fazer maior e mais bonito. O que é muito louvável sem dúvida. A questão porém é que esse bonito é sempre importado. Daí o desastre estético-urbano. Lembram-se de construir uma catedral. Está certo. Mas a quem encomendam o projeto? A um alemão. E o alemão surge com uma coisa em estilo gótico. E essa coisa é aceita e está sendo feita..." [Machado apud Sevcenko, 1992: 119].
}

Quais os efeitos dessa dinâmica, na longa duração? Entre outros, as várias reformas - construções e destruições - pelas quais o Largo/Praça da Sé passa 
em menos de cem anos e que fazem com que, no momento mesmo em que a Catedral é quase que completamente concluída, já não haja mais muito que comemorar: a Praça deixou, há algum tempo, de ser a área valorizada que era quando o projeto da nova Catedral foi desenvolvido: o glamour atravessou o Viaduto do Chá e tomou conta da Avenida Paulista, da Rua Augusta, dos Jardins...

Tudo isso contribui para que espaços como o antigo Largo/ "moderna" Praça da Sé acabem por se constituir em metáforas da dinâmica cultural que se engendrou na cidade no final do século passado, a partir do momento em que surgiu, ancorado no lema do "progresso", o projeto de transformar o passado colonial da cidade em resíduo arqueológico a fim de permitir o futuro glorioso da "civilização paulistana". Ao acompanhar a história de São Paulo desde os seus primórdios e ser objeto de mudanças radicais nos últimos cem anos, a Praça fala da ânsia das elites paulistanas em projetarem no espaço geográfico da cidade os símbolos do sucesso econômico e político de São Paulo - e da sua decadência, a partir do final da década de 20 . Ao lado disso e exatamente por isso, a Sé revela também o resíduo que resiste e persiste para além daquilo que não ficou.

Parece que, no momento em que os projetos de modernidade planejados por cidades como São Paulo deixam de ser projetos e se materializam no seu espaço físico, tornam-se dejetos sem sentido. Eis o que dá sentido à famosa frase de Claude Lévi-Strauss a respeito de cidades como São Paulo: “elas vão do frescor à decrepitude, sem parar na madureza" (1957: 96).

Os cartões do Largo/Praça analisados se destacam por serem representações simbólicas da dinâmica cultural engendrada na cidade a partir de fins do XIX. Suas imagens corporificam a mensagem que São Paulo quer que seja veiculada a seu respeito: é uma cidade "moderna", por mais que o que se considera "moderno" varie ao longo do tempo. O mais decisivo é que, em São Paulo, o "moderno" continue novo...

O "novo" está no futuro e deve ser atingido a todo custo. O preço disso é a destruição da tradição incorporada e referenciada no espaço, de forma que o código de identidade que o paulistano estabelece com o seu passado tem de, obrigatoriamente, passar pelas imagens, eternizadas nas fotografias e nos cartões postais, pois que só elas contêm os locais da infância, da adolescência, da saudade. Retratando os espaços e símbolos paulistanos, retratam o paulistano, pois que os símbolos são as pessoas. Assim, a Catedral, metáfora do hoje exatamente por se situar no amanhã, reflete a alma paulistana, sempre em movimento rumo a algo que não conhece mas que deve ser bom porque não é ainda, mas pode vir a ser, no futuro.

Observando a Catedral, em eterna construção, o mais paulistano dos paulistanos, Mário de Andrade, já havia notado que é nas frestas dos projetos de modernidade propostos para São Paulo desde o final do século XIX que germina a "minha alma" paulistana. Tal como "a catedral de São Paulo", que "nunca se acaba", a "alma" do poeta, do paulistano, não se acaba: está em eterna constru- 
ção. Mesmo "feita de pedras bonitas", o todo da Catedral é "horrível" - "como minha alma". Perspicazmente, Mário sabe que o monumento surgiu "da necessidade" - das elites paulistanas, ávidas de símbolos que ilustrassem seu poderio? Sabe também que, mesmo contendo "pedras novas" e modernas, as "antigas" insistem em persistir, lembrando outros tempos, outros espaços - de um mais "sacro (...) edifício"? E prevê Mário o destino da Catedral - que é "de se acabar, mas depois se destruirá" - e de tantos outros elementos do espaço físico paulistano que, "como o meu corpo" material, se transformam em pó.

Ao igualar os vários aspectos da Catedral da Sé a "minha alma", o poeta fala de seu estado interior, que se reflete no templo. Mas também revela a via pela qual se constrói a identidade paulistana. O paulistano se vê nos seus monumentos, utiliza-se deles como espelhos para entender a sua cidade e a si mesmo. E o que acontece com sua identidade se os seus espelhos são destruídos "em poucas décadas, e sem necessidade"28?

Ela "nunca se acaba", por mais que perca o seu sustentáculo físico - o "meu corpo", que "há de se acabar, mas depois se destruirá". Afinal, essa identidade é tão fragmentada e fugidia como os símbolos que é capaz de construir e destruir, de forma que vive exatamente do refazer o desfeito e vice-versa. Como? Retratando o ainda nascente, fotografando o agora existente, estudando o já decadente.

\section{Notas}

1 Este artigo é produto de uma pesquisa exploratória realizada no âmbito do trabalho de final de curso da disciplina de graduação "Antropologia Visual”, no segundo semestre de 1996. Ele não teria sido possível sem o auxílio de várias pessoas, às quais cabe aqui agradecer: ao colecionador particular Sr. João Emílio Gerodetti, que, sempre solícito e amigável, colocou à minha disposição os cartões postais da Praça da Sé e me forneceu informações preciosas; à fotógrafa Inês de Castro, do Laboratório de Imagem e Som em Antropologia da USP, que reproduziu fotograficamente as imagens dos cartões do Sr. Gerodetti; ao gerente da empresa Jardineira Veículos Zareh Chouchanian, cujas informações sobre automóveis antigos me foram de muitíssima utilidade; ao Monsenhor Jamil Nassif Abib, profundo conhecedor de

população. E co-autora da antologia (Des)figurações: a vida cotidiana no imaginário onírico da metrópole, São Paulo, Editora Hucitec,1996.

3 Parente \& Monte-Mór (1990) descrevem o desenvolvimento das modernas técnicas de reprodução fotográfica: a descoberta do negativo e da possibilidade das ampliações e cópias em papel. 
4 Assim registra Kyrou que, em 1899, momento de ascensão do cartão, a Alemanha, contando com 50.000.000 habitantes, produz 88.000 .000 de cartões, superando em muito outros países como a Inglaterra (38.500.000 de habitantes, 14.000 .000 de cartões produzidos), a Bélgica (6.200.000 de habitantes, 12.000 .000 cartões) e a França, cujo número de cartões produzidos é bem inferior à sua quantidade de habitantes $(8.000 .000$ de cartões para 38.000.000 habitantes) (Kyrou apud Kossoy, 1978).

5 Boris Kossoy (1988) e Parente \& Monte-Mór (1990) discorrem mais pormenorizadamente sobre a biografia desses homens, responsáveis por grande parte das mais conhecidas imagens que se têm sobre as duas cidades, no fin de siècle.

6 Conta o arquiteto Carlos Lemos que o comércio ainda não toma conta do Largo, ficando relegado às "ruas estreitas, como a nossa rua Direita, a de São Bento e da Quitanda", uma vez que "as praças nunca foram bons pontos de loja, principalmente aquelas das igrejas" (Lemos apud Miyasaki et alii, 1979: 3).

7 Esclareceu-me Monsenhor Jamil que matriz é um termo que designa a igreja-mãe da paróquia e que serviu, no século XVI, para denomiar o templo erigido no local onde hoje se situa a Praça da Sé. Assim que o território é elevado a diocese, a matriz se torna catedral. Em São Paulo, isso ocorreu em meados do XVII, levando à construção de uma catedral da sé ("sé" significa "sede da diocese"), que é o edifício que persistirá até 1912, e a uma nova denominação do local em frente ao templo: Largo da Sé.

8 Ou seja, como denominação dada aos processos de racionalização e de industrialização capitalista, baseados em valores como "progresso" e "civilização", que se originam na Europa principalmente no século XIX.

9 Ver, na figura 1 em anexo, uma planta que esquematiza a localização do Largo da Sé entre 1860 e 1913.

10 Ver, na figura 2 em anexo, uma segunda planta esquemática da localização do Largo/Praça após a derrrubada dos quarteirões, em 1912 e que permanecerá até 1972, quando nova reforma acontece, a fim de que a Praça da Sé se torne principal ponto de entroncamento do transporte metroviário paulistano.

11 Um sintoma da decadência da Praça é a mudança de usos por que passa o Palacete Santa Helena. Inaugurado em 1922, esse edifício de luxo, com "um dos maiores e melhores cineteatros de São Paulo, assim como um dos primeiros cabarés elegantes da cidade", pisos de mármore italiano, metais ingleses, vidros tchecos, telhas francesas, teve seus andares superiores alugados "por empresas modestas, pequenas firmas, pintores que se iniciavam" (e que vieram constituir o Grupo Santa Helena: Alfredo Volpi, Aldo Bonadei, etc.), enquanto o cinema do andar térreo se torna veiculador de filmes pornográficos (Miyasaki et alii, 1979: 30).

12 Ver, como exemplo disso, mais adiante, o cartão $n^{\circ} 2$.

13 Ver o ângulo fotografado na figura 1, em anexo. 
14 Ver o ângulo fotografado na figura 1, em anexo.

15 Os lampiões elétricos, com um aspecto bem característico que veremos em outros cartões, passam a ser implantados na cidade em 1900 (cf. Bruno, 1954; Morse, 1970).

16 O que Barthes chama de "mensagem símbólica" é transmitido por meio de signos descontínuos, sendo sua possibilidade de leitura condicionada pelo "saber investido na imagem (saber prático, nacional, cultural, estético)" (1990: 38). Trata-se, nesse caso, do aspecto conotativo da imagem, que, segundo Barthes, "é histórico (...) ou, se se prefere: "cultural'; os signos são nela gestos, atitudes, expressões, cores ou efeitos, dotados de certos sentidos em virtude do uso de uma certa sociedade" (Barthes, 1982: 20).

17 "Não às epidemias, à multidão!" é o lema. O doente deve ser afastado? Constróm-se o Hospital de Isolamento, em 1880; os Sanatórios Populares para Tuberculosos, em 1899. O louco, isolado? Eis que surge o novo Hospício dos Alienados, em 1895. As crianças necessitam ser educadas? A Escola Caetano de Campos é construída pelo famoso arquiteto Ramos de Azevedo, em 1894. A pobreza deve ser controlada? Eis o Asilo da Mendicidade de 1885, eis as vilas operárias construídas ao longo dos trilhos do trem dos bairros pobres (Brás, Móoca, Belenzinho) (Rago, 1985).

18 Termo barthesiano que se refere fundamentalmente à linguagem textual presente nas imagens fotográficas e cuja função é "fixar a cadeia flutuante de significados, de modo a combater o terror dos signos incertos" (1990: 32). No caso dos cartões postais, é através da "mensagem linguística" que se revela, para o consumidor dos cartões, a função dos "títulos" e legendas destes, situados - dentre os cartões da época analisada aqui - sempre ao lado ou no interior da imagem fotografada: devem identificar os locais retratados, comprovar que se "esteve aqui" e que esse aqui tem nome.

19 Ver o ângulo fotografado na figura 2, em anexo.

20 Ver o ângulo fotografado na figura 2, em anexo.

21 Enfatiza Sevcenko que "depois da Guerra e com sua incorporação ao serviço de táxis urbanos, os automóveis vão ter o seu boom ao longo da década de 20, bloqueando com seu volume os estreitos espaços de circulação da área central e transformando a cidade num autêntico inferno" (1992: 74).

22 Monsenhor Jamil confirma a inexistência de imagens fotográficas do primeiro período de construção da Catedral, quando ainda não existia ainda nenhum pedaço substantivo erigido, com exceção de pedras empilhadas. Dessa forma, os cartões da Praça da década de 1920 e 1930 focalizam, além do ângulo do cartão que estamos analisando, primordialmente o Palacete Santa Helena, enquanto à Catedral mesmo ficam relegados uma aparição e um papel secundários.

23 Conta Sevcenko que, na década de 20, é aprovado na Câmara Municipal um projeto que impõe a altura mínima de três pavimentos para qualquer edificação construída no centro da cidade (1992: 117). 
24 A partir deste momento - final da década de 1920 - até o final dos anos 60 - quando a Catedral é concluída - especificamente este ângulo de enquadramento será mantido na grande maioria dos cartões que retratam a Praça. Ver o ângulo fotografado neste cartão e nos seguintes, de 8 a 13, na figura 2 , em anexo.

25 Ver detalhes em Lévi-Strauss, 1996.

26 Ver o ângulo fotografado na figura 2, em anexo.

27 Monsenhor Jamil enfatiza que o material utilizado nas torres é cimento armado, em contraposição ao que prevalece na construção das bases do edifício. Uma vez que a construção tinha ficado muito cara, os construtores tiveram de alterar o projeto original, desvirtuando a concepção primeira da Catedral.

28 Como diz Benedito Lima de Toledo a respeito do parque do Vale do Anhangabaú (1981: 67).

* As legendas dos cartões que não aparecem nas imagens por problemas técnicos estão mencionadas ao longo do texto.

\section{Bibliografia}

ABRIL CULTURAL

1980

ANDERSON, $P$.

1986 "Modernidad y revolucion". In: Cuadernos del Sur, 4:124-8.

ANDRADE, $M$.

1976 Poesias completas, São Paulo, Círculo do Livro.

BARTHES, R.

1990 “A Retórica da Imagem”. In: O Óbvio e O Obtuso. Ensaịos Críticos III. Rio de Janeiro, Nova Fronteira.

1995 "La Chambre Claire". In: Marty, Éric. Roland Barthes. Oeuvres Complètes. Tomo 3 (1974-1980). Paris, Éditions du Seuil.

1982 “Le Message Photographique". In: L'Obvie et l'Obtus. Essais Critiques III. Paris, Éditions du Seuil.

\section{BERGER, J.}

s.d. Modos de ver, Madrid, Editorial Gustavo Gili, S.A.

BRUNO, E.S.

1954 História das tradições da cidade de São Paulo, Rio de Janeiro, José Olympio, Cem Anos de Propaganda no Brasil, São Paulo, Abril Cultural, 1980. 
CORBIN, A.

1995 "O Segredo do Indivíduo". In: Ariès, Philippe \& Duby, Georges (orgs.) História da vida privada: da Revolução Francesa à Primeira Guerra, São Paulo, Companhia das Letras.

DURKHEIM, É.

1937/1922 Les formes elémentaires de la vie religieuse, Paris, Librairie Félix Alcan.

INSTITUTO CULTURAL ITAÚ

1994 A Praça da Sé, 2a edição, Instituto Cultural Itaú.

JULIÃO, L.

1992 Belo Horizonte: Itinerários de Uma Cidade Moderna, 1891-1920, dissertação de Mestrado em História Social, Belo Horizonte, UFMG.

KOSSOY, B.

1980 A Fotografia como fonte histórica: introdução à pesquisa e interpretação das imagens do passado, São Paulo, Museu da Indústria, Comércio e Tecnologia de São Paulo.

1978 “O Cartão Postal". In: Iris, 308.

1988 São Paulo, 1900, São Paulo, CBPO.

LEFEBVRE, $\mathrm{H}$.

1986 Le retour de la dialectique, Paris, Messidor/Éditions Sociales.

LEITE, M.M.

1993 Retratos de família, São Paulo, EDUSP, FAPESP.

LÉVI-STRAUSS, C.

1957 Tristes trópicos, São Paulo, Anhembi Ltda.

1996 Saudades de São Paulo, São Paulo, Companhia das Letras.

MARTINS, A.E.

1911 São Paulo antigo (1554-1910), 1 volume, São Paulo, Livraria Francisco Alves.

MIYAZAKI, EA. et alii

1979 A Praça da Sé, TGI, FAU/USP.

MORSE, R.

1970 Formação histórica da cidade de São Paulo (De Comunidade à Metrópole), São Paulo, Difusão Européia do Livro.

MOURA, P.C.

1943/s.d. São Paulo de outrora: evocações da metrópole, $2^{\text {a }}$ edição. São Paulo, Livraria Martins.

PARENTE, J.I. \& MONTE-MÓR, P.

1990 Rio de memórias, Rio de Janeiro, Interior Produções Ltda. 
POLS, R.

1993/1990 Dating Old photographs, Birmingham, Countryside Books.

SAHLINS, $M$.

1990 Ilhas de história, Rio de Janeiro, Zahar.

SANTOS JR., W.R.

1991 São Paulo: Praça da Sé. Transformações e usos, Dissertação de Mestrado em Arquitetura. São Paulo, FAU/USP.

\title{
SCHWARCZ, L.K.M.
}

1994 Virando Vinte: imaginário paulistano em finais do século XIX, Secretaria de Estado da Cultura, Departamento de Museus e Arquivos.

1987 Retrato em Branco e Negro, São Paulo, Companhia das Letras.

SEVCENKO, N.

1992 Orfeu extático na metrópole, São Paulo, Cia das Letras.

\section{SMRECZSÁNYI, T.}

1986 "A era dos trustes e cartéis". In: História \& Energia. A Chegada da Light, 1, Eletropaulo, Eletricidade de São Paulo, S.A.

SONTAG, S.

1986 “Na Caverna de Platão". In: Ensaios sobre Fotografia. Lisboa, Publicações Dom Quixote.

TOLEDO, B.L.

1981 São Paulo: três cidades em um século, São Paulo, Livraria Duas Cidades.

\begin{abstract}
This article is a result of my first considerations about the use of the postcard as a source of anthropological analysis within a mastership research about the ruptures and continuities experienced by the inhabitants of São Paulo in face of the snciocultural transformati'ns the city has gone through since the 1870s. In a scenery of Ouro-Preto-turning -into-Paris, which city images does the postcard, emerging in São Paulo at the end of the 19th century, contain? Conceiving the postcard as a symbolic representation of the constitution of a whole cultural dynamic which reflects itself deeply in the relation of identity the "paulistano" has started to build up towards his city, the goal here is trying to understand which city-dimensions thirteen images produced between the end of the 19th century and the 60s of our century express, assuming they are the way in which rapidly changing and growing São Paulo sees itself and wants to be seen by the spacially and/or temporally distant "other".
\end{abstract}

Uniterms: São Paulo, turn of the 20th century, symbols of modernity, cultural dynamics, postcard. 


\section{Anexo}

Fonte: Instituto Cultural Itaú

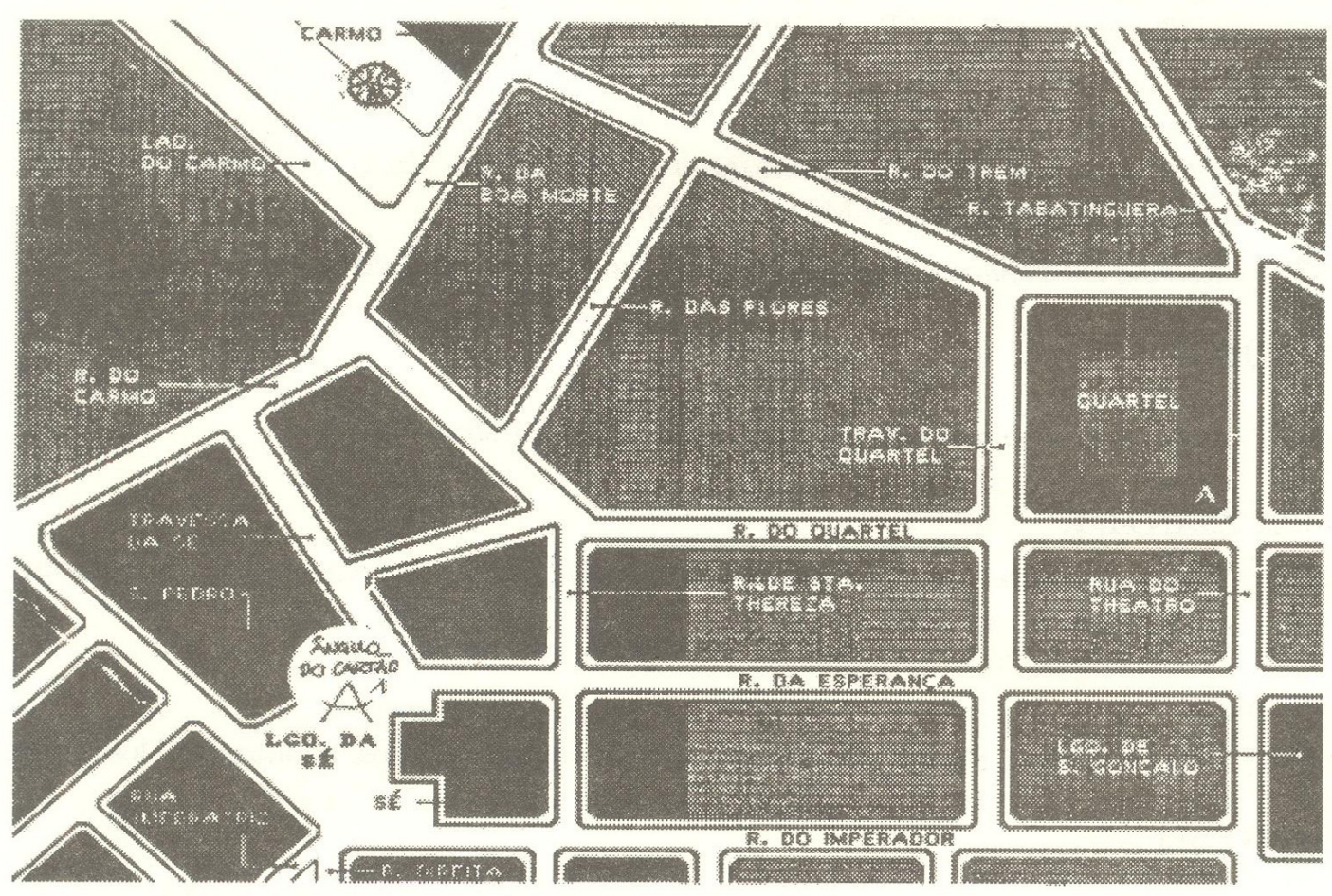

Figura 1

Ernani da Silva Bruno situa a antiga Igreja da Sé: "seus fundos correspondiam mais ou menos à altura da rua Barão de Paranapiacaba, de modo que sua fachada era fronteiriça da igreja de São Pedro, no ponto em que agora existe o edifício da Caixa Econômica. E toda a parte superior do largo de agora era ocupado por vasto quarteirão limitado pelas ruas do Imperador (depois Marechal Deodoro), da Freira (Senador Feijó) e pelo beco do Mosquito, além de um prolongamento da antiga rua de Santa Teresa" (1954:1011). 
Fonte: Instituto Cultural Itaú

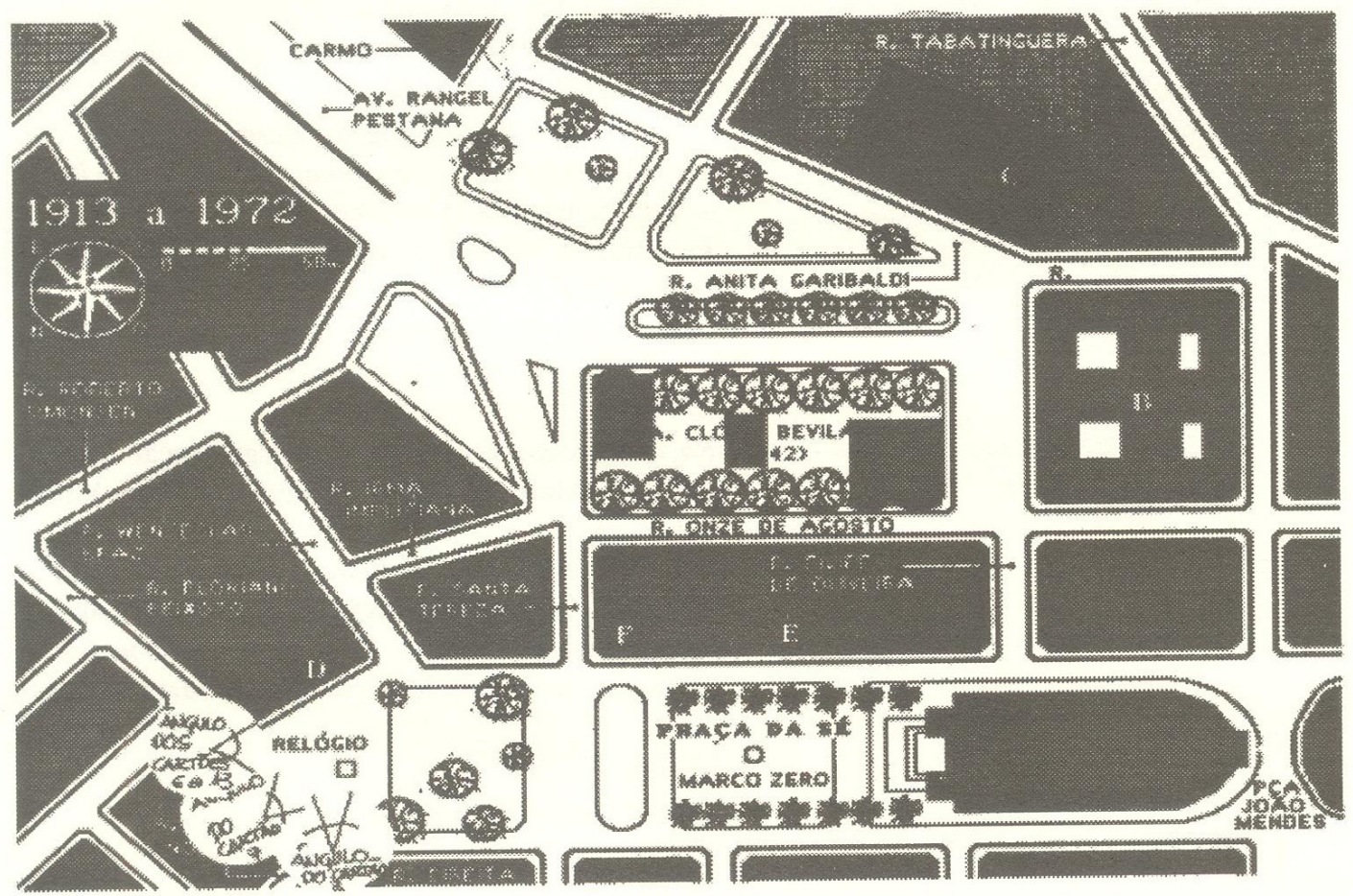

Figura 2

"A princípio estabelecera-se que [a Catedral] devia ser levantada no local da antiga. Mas observou-se que dessa forma não teria o realce pedido por sua estrutura monumental. Decidiu-se então aproveitar em maior extensão ã área aberta com a demolição de velhos quarteirões, ampliando-se o largo da Sé. E transferir-se a nova Sé para o trecho mais alto da esplanada, ali se erguendo a nova construção de modo a ter sua fachada posterior no alinhamento da praça João Mendes" (Bruno, 1954:940). 


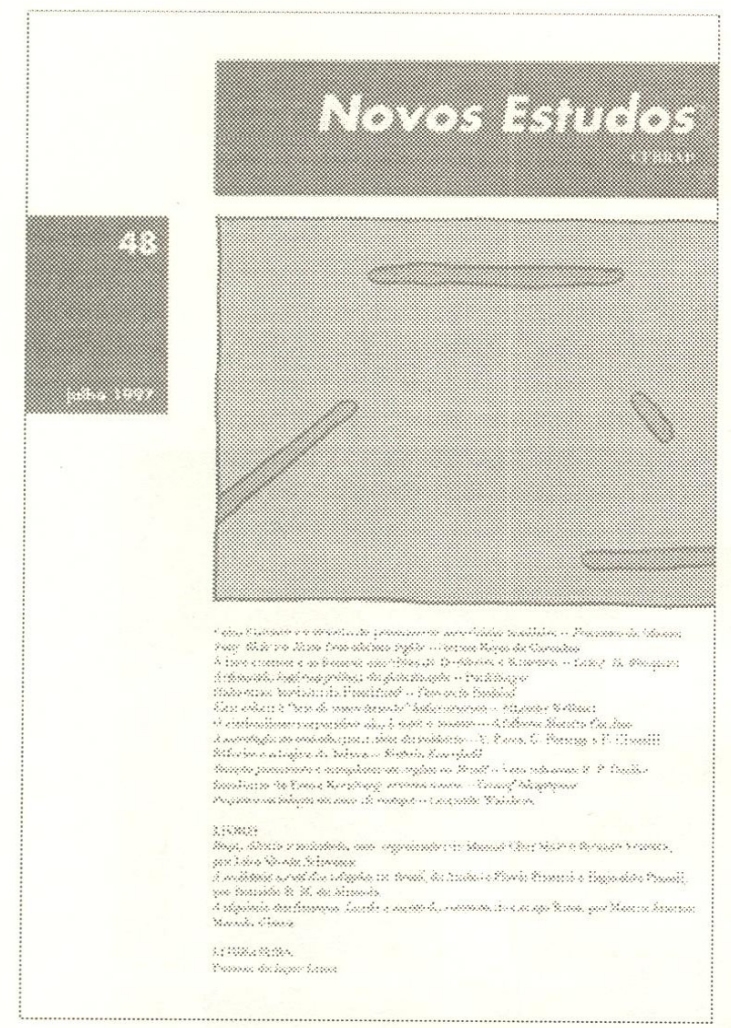

Celso Furtado e o desafio do pensamento autoritário brasileiro - Francisco de Oliveira, Toni Blair e o Novo Tarbalhismo Inglês - Nelson Rojas de Carvalho A base comume as fissuras nas obras de Durkheime Bordieu - Lö̈c J.D. Wacquant A dimensão histórico-politica da globalização-Paul Singer

Habermas: herdeiro de Frankfurt? - Fernando Haddad

Uma crítica a "tese do entendimento" habermasiana - Albrecht Wellmer

O sindicalismo corporativo não é mais o mesmo Adalberto Moreira Cardoso

A sociologia do trabalho para além da indústria - V. Paiva, G. Pontegy e F. Chinelli

Sófocles e a lógica da beleza - Katrin Rosenfeld

Doação presumida e transplante de órgãos no Brasil - Vera Schattan R.P. Coelho

Esculturas de Franz Krajcberg: árvores-totens - Youssef Ishaghpour

Pequena sociologia danota de rodapé-Leopoldo Waizborg

\section{LIVROS}

Raça, ciência e sociedade, com organização de Marcos Chor Maio e Ricardo Ventura, por Lilia Moritz Schwarcz

A realidade social das religiões no Brasil, de Antônio FlávioPieruccie ReginaldoPrandi,por Ronaldo R.M.de Almeida A alquimia das finanças. Lendo a mente do mercado, de George Soros, por Marcos Antonio Macedo Cintra

LITERATURA

Poemas de Jayro Luna

\section{Novos Estudos}

CEBRAP

\section{ASSINATURA}

Nacional (sujeito a revisão)

para 1 ano (3 números)

para 2 anos (6 números)

Internacional

Número avulso
$\mathrm{R} \$ 30,00$

$\mathrm{R} \$ 55,00$

US\$70,00

$\mathrm{R} \$ 12,50$

Envie seu pedido com cheque nominal para:

Editora Brasileira de Ciências

Rua Morgado Mateus, 615 - CEP 040015-902 - São Paulo - SP

Tel: (011) 574-0399 Fax: (011) 574-5928

Para usar seu cartão Credicard, Mastercard ou Dinners Club, ligue (011) 574-0399 